\title{
Kuzeydoğu Anadolu Petrogliflerindeki Bir Grup Dağ Keçisi Motifi*
}

\section{A Group of Mountain Goats Motif in Northeastern Anatolian Petroglyphs}

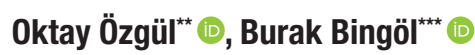

\section{Öz}

Yüksek bir plato özelliği taşıyan Doğu Anadolu Bölgesi kaya resimleri açısından oldukça zengindir. Ardahan, Kars, Erzurum, Erzincan ve Van-Hakkâri dağlık bölgesi kaya resimleri, bu zenginliğin büyük bir kısmını oluşturur. Bölgedeki andezit ve bazalt taşlara çizilen kaya resimlerinde genellikle çizgi, kazıma, oyma ve gagalama tekniğinin kullanıldığı görülür. Kaya resim alanlarında karşılaşılan motifler, insan (şaman), at, boğa - öküz - inek, geyik, kurt, köpek, koyun - koç - dağ keçisi gibi motiflerdir. Bunların yanı sıra av ve savaş sahneleri, tören ve geometrik sahneler ile gökyüzü şekilleri de işlenen diğer temalar arasındadır. Kuzeydoğu Anadolu bölgesinde 16 kaya resim alanı tespit edilmiştir. Çalışmada incelenen 9 merkez; Çıldır Başköy, Borluk Vadisi/Azat köyü, Camuşlu, Digor/Dolaylı, Geyiklitepe, Kurbanağa, Dilli Vadisi, Cunni Mağarası ve Şenkaya Kaynak köyü kaya resimleridir. Bu resimlerde 368'ten fazla figür mevcut olup bunların 119'u dağ keçisi figürüdür. Çalışmada, ilgili kaya resim alanlarındaki dağ keçisi motifinin morfolojisi incelenerek, sembolik anlamı, av ritüelindeki ve muhtemel kozmik dünyadaki yeri tartışılmıştır.

\section{Anahtar Kelimeler}

Kaya resimleri, dağ keçisi, göçer kültür, Kuzeydoğu Anadolu

\section{Abstract}

The Eastern Anatolia region, a high plateau, is exceptionally rich in paintings on rocks. Rock paintings in Ardahan, Kars, Erzurum, Erzincan, and Van-Hakkari mountainous region constitute a large part of this wealth. The technique of line, engraving, carving, and pecking was generally used in rock paintings drawn on andesitic and basalt stones in the region. The motifs encountered in rock painting areas are human (shaman), horse, bull - ox - cow, deer, wolf, dog, and sheep - ram mountain goat. Furthermore, scenes of hunting and war, ceremonial and geometric scenes, and celestial shapes are among the covered themes. Sixteen rock painting areas were identified in the Northeast Anatolian region. Nine centers were examined in the study; Çıldır Başköy, Borluk Valley/Azat village, Camuşlu, Digor/Dolaylı, Geyiklitepe, Kurbanağa, Dilli Valley, Cunni Cave, and Şenkaya Kaynak village are rock paintings. There are more than 368 figures in these paintings, of which 119 are mountain goat figures. In the study, the morphology of the mountain goat motif in the related rock painting areas was examined, and its symbolic meaning and place in the hunting ritual and the possible cosmic world were analyzed.

\section{Keywords}

Rock arts, mountain goat, nomad culture, Northeastern Anatolia

* Bu makale Atatürk Üniversitesi Türkiyat Araştırmaları Enstitüsü, Eskiçağ Tarihi Anabilim Dalı́nda Doç. Dr. Oktay ÖzGÜL danışmanlığında Burak BiNGÖL tarafindan hazırlanan, "Kuzeydoğu Anadolu Petrogliflerindeki Dağ Keçisi Motifi” başlıklı yüksek lisans tez çalışması temel alınarak hazırlanmıştır.

** Sorumlu Yazar: Oktay Özgül (Doç. Dr.) Türkiye-Kırgızistan Manas Üniversitesi, Edebiyat Fakültesi Tarih Bölümü, Bişkek, Kırgızistan. E-posta: oktay.ozgul@manas.edu.kg, ORCID: 0000-0003-0575-0436

*** Burak Bingöl (Arş. Gör.) Recep Tayyip Erdoğan Üniversitesi, Fen-Edebiyat Fakültesi, Tarih Bölümü, Rize, Türkiye. E-posta: burak.bingol@erdogan.edu.tr, ORCID: 0000-0003-4660-5091

Attf: Ozgul, Oktay ve Bingol Burak. "Kuzeydoğu Anadolu Petrogliflerindeki Bir Grup Dağ Keçisi Motifi." Art-Sanat, 16(2021): 491-527. https://doi.org/10.26650/artsanat.2021.16.0017 


\section{Extended Summary}

The mountainous region of Eastern Anatolia has wide plateaus and many rivers extending from mountains to plains through valleys. Considering the land conditions and climate structure, the suitability of the region for nomadic cultures throughout history is striking.

Nomadic cultures left many cultural elements, such as kurgans, tombs, stamps, stone statues, runic writings, and rock paintings in the areas they lived. During the archaeological investigation conducted in the region, all of these samples were found. Among them, rock paintings are particularly intense.

Rock paintings are symbols that people drew or painted to express themselves on cave walls, rocks, or rock blocks since ancient times. The figures in rock paintings were generally found in the area we examined. In addition to individual objects, such as human, horse, bull - ox - cow, deer, tiger - lion, eagle, wolf, dog, and sheep - ram - goat, various hunting and war scenes and ceremonial scenes were observed in groups. Besides, geometric shapes and sky shapes were frequently processed images. Among all these motifs, the mountain goat motif draws attention both numerically and as an embroidery detail. In this study, mountain goat motifs in Northeast Anatolian petroglyphs were investigated. The study identified and examined 119 mountain goat motifs in nine centers.

Dating is the greatest problem in rock paintings. As studies in the region are still in their early stages and scientific analysis is lacking, the issue of dating the rock paintings has not been finalized. E. Anati, who investigates rock paintings in Anatolia, studied Karain, Öküzini, Tırşin, Gevaruk, and Çatak rock paintings and made groupings for a dating method. Considering these examples, the analogical and archaeological methods were used throughout the dating studies on Northeast Anatolian petroglyphs. To analyze the rock paintings and to shed light on the origin issue, these paintings were first compared with the rock painting areas in nearby regions, such as Van-Hakkari. Subsequently, similarities and differences with the rock paintings in Northwest Iran, Armenia, and Azerbaijan were analyzed.

The findings of the study indicated that rock paintings in the region began in the Bronze Age and continued into the Iron Age and the Middle Ages. However, it is possible to evaluate the rock paintings in the region as a part of the "Migratory Animal Style" in terms of form and theme. Considering that this style was carried to Anatolia by the Scythians from the first millennium B.C., more precise results can be obtained. The classification system in this study will contribute to studies in the field until new dating and analysis methods are determined.

In the Northeast Anatolian region, studies were conducted in five centers from Kars, two from Erzurum, and one from both Ardahan and Erzincan, as they are ex- 
emplary and distinctive. The figures encountered in these painting areas are human, mountain goat, deer, horse, wild sheep, cattle, cavalry, sun disc, trap, fox, dog, pig, stamps, and runic inscriptions. The examined rock painting areas are extraordinarily rich in terms of the number of figures. In total, over 368 figures were identified in nine centers. More than 119 of these figures are mountain goat motifs.

When 119 mountain goats identified in the study area were investigated, some distinctive features drew attention. The mountain goats drawn generally consist of three main lines in the form of head, body, and foot. The drawn heads are sometimes evident and sometimes indistinct. Horns on the head were identified. The horns are either exaggerated curved backward or normal horn-shaped. In both horn types, the horns are drawn singly or in pairs depending on the profile angle. The examination of the drawn bodies revealed that the body is drawn schematic, linear, or normal. Smaller horns on the body strengthen the possibility that they are female or children. Besides, the erected phallus, curved exaggerated horns, and erected tails are likely to represent male goats. When the drawn feet were examined, they appeared mobile and immobile. Joints and fingernails are usually evident on mobile legs. The immobile ones are drawn in a flat style. According to the profile angle, the legs are drawn as double or single in both leg types.

As a result, it was inferred that the rock paintings, which emerged mostly from the Early Bronze Age in the Northeast Anatolian plateaus and show periodic differences, are in a similar cultural unity with the rock paintings of the Van-Hakkari mountainous region in close vicinity. Northeast Anatolian rock paintings, similar to those in Northwest Iran, Armenia, Azerbaijan, and Nakhchivan in the secondary cultural environment, are related to the rock painting art of the Eurasian continent in terms of origin. The similarities of nomadic cultural elements, such as the Hakkari Steles, other Central Asian statues and stamps from Eastern Anatolia, and some kurgan-type tomb structures, can be assessed collaboratively to understand the region's relationship with nomadic cultures in B.C. II. It was unthinkable that the steppe culture and art, which spread over an area of approximately 10 million $\mathrm{km} 2$ from the first millennium B.C., could be transmitted across the region. Despite chronology and partial origin issues, the continuation of the animal style in rock paintings with some changes and self-renewal is one of the most distinctive features of steppe art. From this aspect, Northeastern Anatolian rock paintings reflect various forms of this art by preserving its essence. 


\section{Giriş}

Doğu Anadolu Bölgesi dağlık bir coğrafyaya sahiptir. Bölge, dağların üzerinde bulunan geniş platolara ve yine dağlardan ovalara vadilerce uzanan birçok akarsuya sahiptir. Arazi şartları ve iklim yapısı da dikkate alındığında bölgenin tarih boyunca göçer kültürlere uygunluğu göze çarpmaktadır ${ }^{1}$. Göçer ${ }^{2}$ kültürler yaşadıkları alanlarda birçok maddi kültür öğesi bırakmışlardır. Bunları kurganlar, mezarlar, damgalar-enler, taş heykeller, runik yazılar ve kaya resimleri olarak sıralamak mümkündür. Bölgede yapılan arkeolojik yüzey araştırmalarında bu örneklerin tamamına rastlanmıştır. Bunlar içinde kaya resimleri ise oldukça yoğundur. Anadolu da henüz çok yeni olan kaya resim araştırmaları ile ilgili ola-

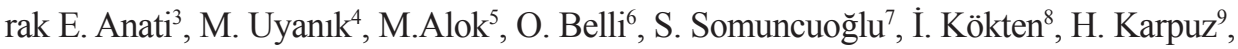

1 Alpaslan Ceylan, Doğu Anadolu Araştırmaları Erzurum-Erzincan-Kars-Iğdır 1998-2008 (Erzurum: Güneş Vakfı Yayınevi, 2008), 33-44; Oktay Özgül, "Eskiçağda Yukarı Aras Vadisi” (Doktora Tezi, Atatürk Üniversitesi, 2011), 13-30; Yavuz Günaşd1, "Karasu (Yukarı) Havzasındaki Tarihi ve Arkeolojik Veriler” (Doktora Tezi, Atatürk Üniversitesi, 2013), 8-25; Alpaslan Ceylan, Doğu Anadolu Araştırmaları Erzurum-ErzincanKars-Ĭgdır 2008-2014 (Erzurum: Atatürk Üniversitesi Yayınevi, 2015), 53-79; Burak Bingöl, "Kuzeydoğu Anadolu Petrogliflerindeki Dağ Keçisi Motifi” (Yüksek Lisans Tezi, Atatürk Üniversitesi, 2020), 6-21.

2 Türkçe sözlükte "göçer" kelimesi, "göçebelik" şeklinde kullanılmıştır. Aynı sözlükte göçebelik kelimesi, göçebe olma durumu, bir toplumsal birliğin, yaşamak için gerekli kaynakları elde edebilmek üzere düzenli aralıklarla yer değiştirme geleneğinde veya alışkanlığında olması ile açıklanmıştır. Türk Dil Kurumu, Türkçe Sözlük, (Ankara: Türk Dil Kurumu Yayınları, 2010), 955. Göçer-göçebelik ve nomadizm kelimelerinin kavramsal açıklaması hakkında detaylı bilgi için bk. Anıl Yılmaz ve Cahit Telci, "Türk Kültür Terminolojisinde Göç Kavramı Üzerine,” Modern Türklük Araştırmaları Dergisi 7/2 (2010), 14-33; Oktay Özgül ve Nezahat Ceylan, "Göçerlik ve Yerleşiklik Arasında Bir Bileşen; Fergana Vadisi," Prof. Dr. Fuat Sezgin Anısına Geçmişten Günümüze Türkistan: Tarih, Kültür ve Medeniyet Sempozyumu (11-12 Nisan 2019 Türkistan), (Ankara: Ahmet Yesevi Üniversitesi Yayınları, 2019), 472- 495; İlhami Durmuş, “Orta Asya'dan Anadolu’ya Türk Konar- Göçer Kültürü,”, Orta Asya Türk Kültürünün Anadolu Kültürüne Etkileri Uluslararast Sempozyumu (19 Haziran 2019 Taşkent), (Ankara: Hacı Bayram Veli Üniversitesi Yayınları, 2019), 11-35.

3 Emanuel Anati, “Anatolia's Earliest Art," Archaeology 21/1 (1968), 22-35; Emanuel Anati, Arte Prehistorica in Anatolia, Studi Camuni 4 (Italia: Capo di Ponte Edizioni del Centro, 1972).

4 Muvaffak Uyanık, Petroglyphs of South - Eastern Anatolia (Graz: Akademische Druck und Verlagsanstalt), 1974.

5 Ersin Alok, Anadolu'da Kaya Üstü Resimleri (İstanbul: Akbank Yayınları, 1988).

6 Oktay Belli, "Kars - Borluk Vadisi Kayaüstü Resimleri," Arkeoloji ve Sanat Dergisi 122 (2006), 11- 22; Oktay Belli, "Kağızman Karaboncuk'da Tarih Öncesi Döneme Ait Kayaüstü Resimleri," Arkeoloji ve Sanat Dergisi 121 (2006): 1- 10; Oktay Belli, "Van Bölgesi'ndeki Yeni Boyalı Mağara Resimleri," Homo Amatus: Güven Arsebük için Armağan Yazıları, ed., M., Özbaşaran, O., Tanındı ve A., Boratav (İstanbul: Ege Yayınlar1, 2003), 29-42.

7 Servet Somuncuoğlu, Saymaltaş: Gökyüzü Atları (İstanbul: Atok Yayınları, 2011); Servet Somuncuoğlu, Sibiryadan Anadolu'ya Taştaki Türkler (İstanbul: Atok Yayınları, 2011); Servet Somuncuoğlu, Damgaların Göçü Kurgan (İstanbul: İletişimce Fotoğraf ve Danışmanlık Hizmetleri, 2012).

8 İsmail Kılıç Kökten, "Kars Çevresinde Dip Tarih Araştırmaları ve Yazılıkaya Resimleri," Atatürk Konferansları, (1975), 95-104; İsmail Kılıç Kökten, "Yazılıkaya'da ve Kurbanağa Mağarasında (Kars-Çamuşlu) Yeni Bulunan Dip Tarih Resimleri," Karseli 6/69 (1970), 2-16.

9 Haşim Karpuz, "Çamuşlu'da Yontma Taş Çağı Kaya Resimleri," Tübitak Bilim ve Teknik 10/212 (1977), 1-6. 
A. Ceylan ${ }^{10}$, O. Özgül ${ }^{11}$, Y. Günaşd1 ${ }^{12}$, İ. Üngör ${ }^{13}$, A. Bingöl ${ }^{14}$, N. Ceylan ${ }^{15}$, B. Bingöl ${ }^{16}$, C. Sevindi-A. Y. Tavukçu ${ }^{17}$, E. Soydan - F. Korkmaz ${ }^{18}$ gibi bilim insanlarının çalışmaları mevcuttur.

Kaya resimleri, insanın eskiçağlardan beri mağara duvarlarına, kayalara veya kaya bloklarına kendini ifade edebilmesi için çizdiği ya da boyadığı sembollerdir. Çalışma kapsamında incelenen alanda bulunan kaya resimlerindeki figürlerin genelde insan, at, boğa - öküz - inek, geyik, kaplan - aslan, kartal, kurt, köpek, koyun - koç - keçi gibi tekil nesneler ve çeşitli av ve savaş sahneleri, tören sahneleri şeklinde grup içinde olduğu görülmektedir. Ayrıca geometrik şekiller ve gökyüzü şekilleri de sıkça işlenen resimlerdir ${ }^{19}$.

Bütün bu motifler içinde dağ keçisi motifi hem sayısal olarak hem de işleme detayı olarak dikkat çekmektedir. Çalışma için Kuzeydoğu Anadolu Petrogliflerindeki dağ keçisi motifleri araştırılmış ve 9 merkezde 119 dağ keçisi motifi tespit edilmiştir.

10 Alpaslan Ceylan, "Doğuda İlk Türk Yerleşmelerinden Cunni Mağarası,” Türkler Ansiklopedisi, c. 4 (Ankara: Yeni Türkiye Yayınları, 2002), 425-429; Alpaslan Ceylan, “Doğu Anadolu’da İlk Türk İzleri,” XV. Türk Tarih Kongresi I (11-15 Eylül 2006), (Ankara: Türk Tarih Kurumu Yayınları, 2006), 215-232; Alpaslan Ceylan, "Çıldır Başköy Kaya Resimleri," Ardahan Üniversitesi Insani Bilimler ve Edebiyat Fakültesi Dergisi BELG ̈U 2/2 (2015), 9-24; Alpaslan Ceylan, “Geyiklitepe Kaya Resimleri ve Runik Yazıtları,” III. Uluslararası Türk Şöleni Türk Kültürü Sempozyumu Bildirileri, (17-19 Mayıs 2012 Erzurum), (Erzurum: Güneş Vakfı Yayınları, 2016), 85-96; Alpaslan Ceylan, “Türk Dünyasından Yeni Kaya Resimleri,” XVII. Türk Tarih Kongresi I (1517 Eylül 2014), 2018, 173; Alpaslan Ceylan, “Doğu Anadolu’da Erken Dönem Türk İzleri III Kars-Digor (Dolayl1) Kaya Resimleri,” TTK Kongresi’nde Sunulan Bildiri, Ankara, 1 - 5 Ekim 2018.

11 Oktay Özgül, “Erzurum Bölgesi Kaya Panoları,” Trakya Üniversitesi Edebiyat Fakültesi Dergisi 5/10 (2015), 169-188; Oktay Özgül, “Erzurum Şenkaya Petrogliflerindeki At Geyik ve Güneş Kursu,” Selçuk Üniversitesi Türkiyat Araştırmaları Enstitüsü Dergisi 39 (2016), 371-396; Oktay Özgül, “Orta Asya Kaya Resimleri Iş1ğında Kars-Ardahan Kaya Resimlerindeki Av ve Tuzak Sahneleri,” IV Türk Şöleni Bildirileri (17-19 Mayıs 2016 Erzurum), (Erzurum: Güneş Vakfı Yayınları, 2018), 893-911.

12 Yavuz Günaşd1, “Doğu Anadolu Kaya Resimleri Işığında Doyumlu Kaya Panoları,” Selçuk Üniversitesi Türkiyat Araştırmaları Dergisi 1/39 (2016), 391-407.

13 İbrahim Üngör, “Türk Kültüründe Dağ Keçisi Teke,” IV. Uluslararası Türk Şöleni Türk Kültürü Sempozyumu Bildirileri (17-19 Mayıs 2016 Erzurum) (Erzurum: Güneş Vakfı Yayınları, 2018), 245-325.

14 Akın Bingöl, "Yüzey Araştırmaları Işı̆̆ında Borluk Vadisi Kayaüstü Resimleri," Selçuk Üniversitesi Türkiyat Araştırmaları Dergisi 39 (2016), 347-355.

15 Nezahat Ceylan, “Türk Kültüründe Geyik Kavramı Ve Kuzeydoğu Anadolu Kaya Resimlerindeki Geyik Tasvirleri,” IV. Uluslararası Türk Şöleni Türk Kültürü Sempozyumu Bildirileri, (17-19 Mayıs 2016 Erzurum), (Erzurum: Güneş Vakfı Yayınları, 2018), 871-891.

16 Bingöl, "Kuzeydoğu Anadolu Petrogliflerindeki Dağ Keçisi Motifi," 70-176.

17 Cemal Sevindi ve Ali Yalçın Tavukçu, "Şirvaz Kalesi ve Kayaüstü Resimleri Şenkaya Erzurum," Atatürk Üniversitesi Güzel Sanatlar Enstitüsü Dergisi 31 (2013), 155-173.

18 Ersoy Soydan ve Ferhat Korkmaz, "Batman'da Yeni Bir Keşif: Deraser (Arık) Mağara Resimleri,” Turkish Studies - International Periodical For The Languages, Literature and History of Turkish or Turkic Volume 8/6 (2013), 665-686.

19 Bingöl, "Kuzeydoğu Anadolu Petrogliflerindeki Dağ Keçisi Motifi,” 28. 


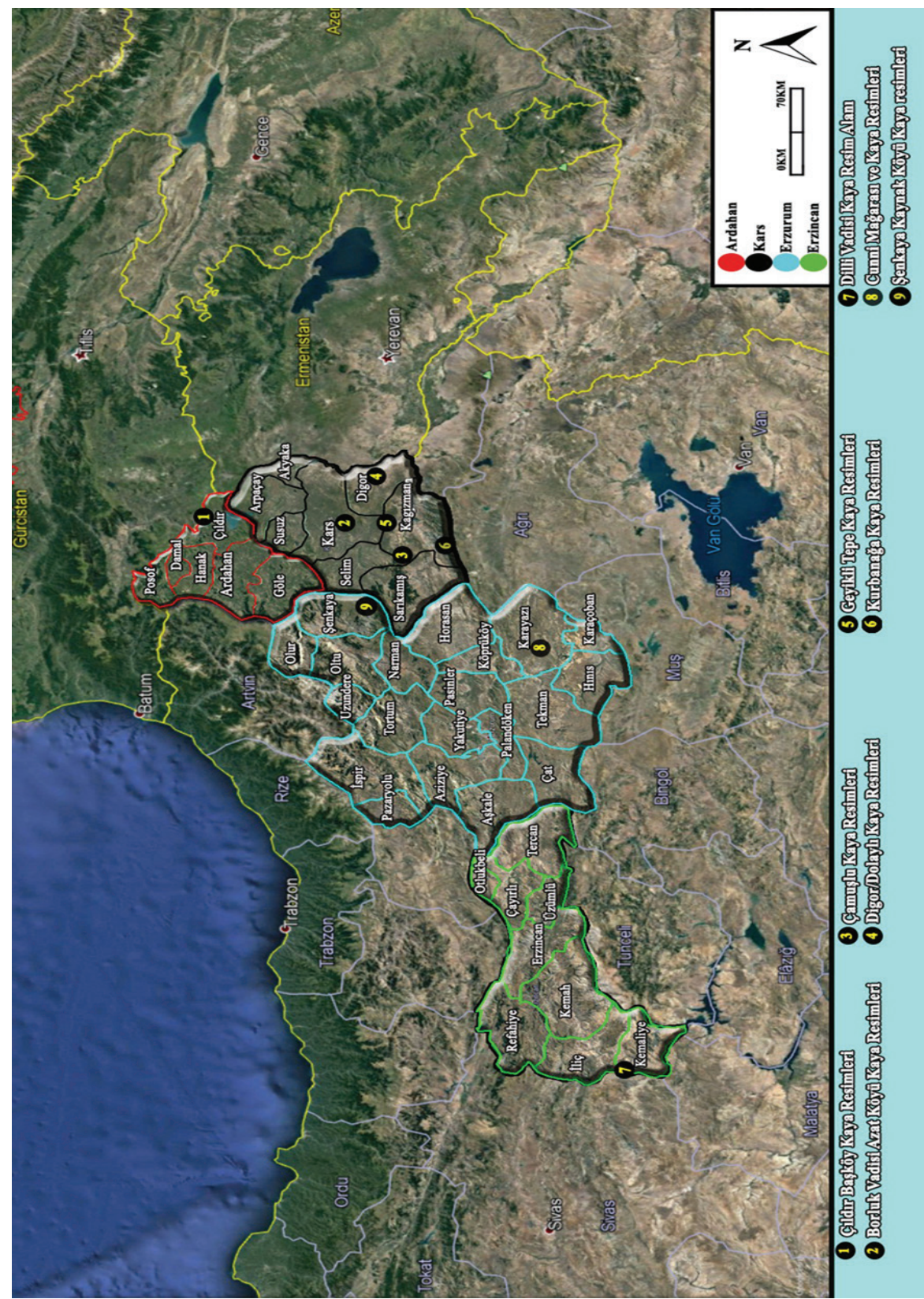

G. 1: Kuzeydoğu Anadolu Bölgesi Kaya Resimleri Çalışma Alanı (O. Özgül - B. Bingöl, 2020.) 


\section{Kuzeydoğu Anadolu Petrogliflerinde Dağ Keçisi Motifi Bulunan Merkezlerden Bazıları}

\section{Çıldır Başköy Kaya Resimleri' ${ }^{20}$}

Çıldır Başköy kaya resimleri Ardahan ili Çıldır ilçesi Başköy köyünün 1.1 km batısında ve Damlıca köyünün ise $1.7 \mathrm{~km}$ doğusunda, $2225 \mathrm{~m}$ rakımda bulunmaktadır (G. 1). Çıldır Başköy kaya resimlerinde süvari, at, köpek ve dağ keçisi motiflerine rastlanılmaktadır. Panoda çizgi ve kazıma tekniği ile 10 süvari, 14 avcı insan, 5 adet dağ keçisi ve 4 adet köpek figürü çizilmiştir. Panonun ana konusu av temasıdır ${ }^{21}$ (G. 2).

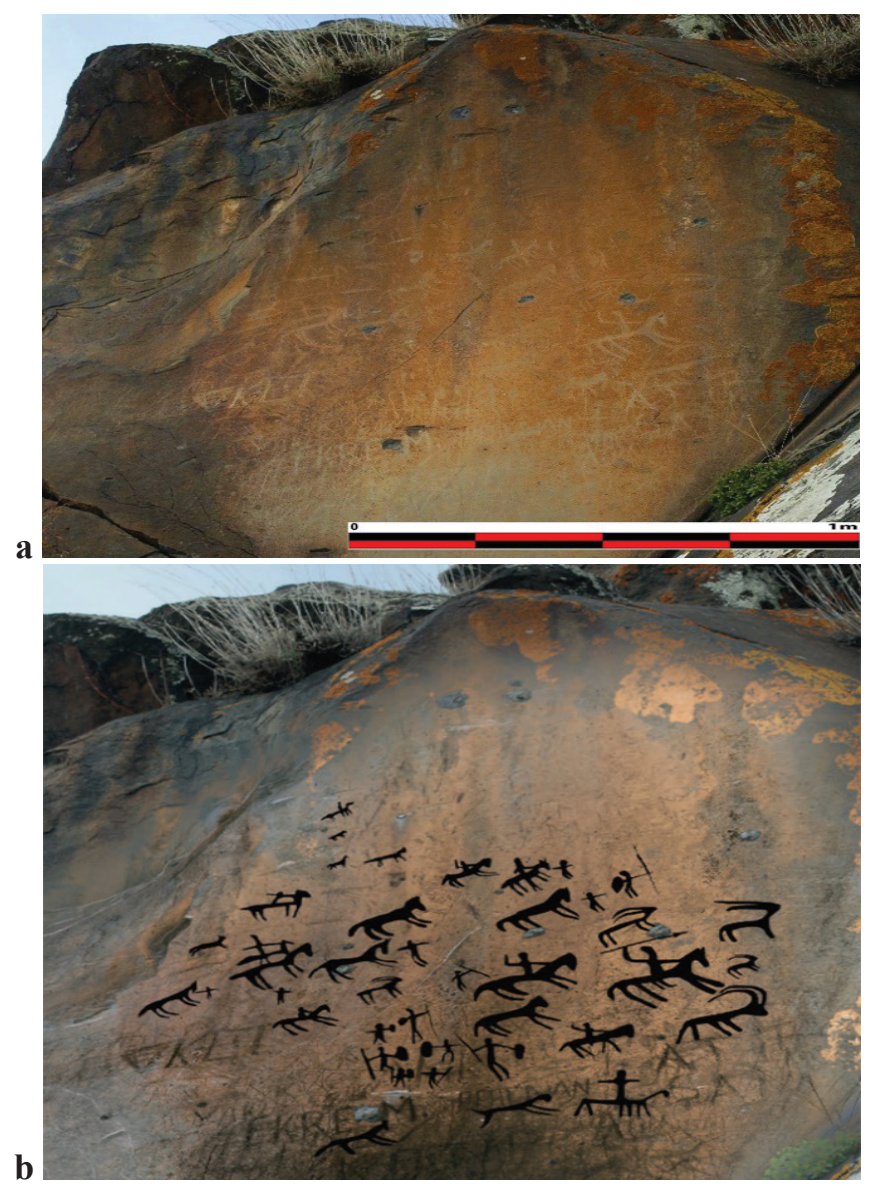

G. 2: a: Çı1dır Başköy Kaya Resimleri Genel Görünümü (A. Ceylan Arşivi). b: Çıldır Başköy Kaya Resimleri Genel Çizimi (A. Ceylan Arşivi). 
Panoda çizgi tekniği ile profilden çizilmiş 5 adet dağ keçisi figürü tespit edilmiştir. Keçi figürleri incelendiğinde hepsinin aynı tema içerisinde olduğu ve aynı teknik ile çizildiği görülmektedir. Figürlerin tamamı aynı yöne doğru haraketli vaziyette çizilmişlerdir. Ancak 5 numaralı dağ keçisi figürünün avcılar tarafından sürüden koparıldığ1 gözükmektedir. Keçi figürlerinin ana hatları belirgin vaziyette çizilmiştir. Boynuzları çok abartılı olmayacak şekilde geriye doğru, bazıları ise kıvrımlıdır. Keçi figürlerinin baş kısımları belli ve vücuda orantılıdır. Gövdeler genelde dikdörtgenimsidir. Figürler, genelde dört ayak da belli olacak şekilde çizilmiştir. Ayaklarda eklem ve tırnak belirgin değildir. Yine figürlerde kuyruk belirtilmemiştir. 2 numaralı keçi figürünün küçük olarak çizilmesi onun oğlak olabilme ihtimalini düşündürmektedir. Boynuzlardan bunların teke olduğu anlaşılmaktadır (G. 3).
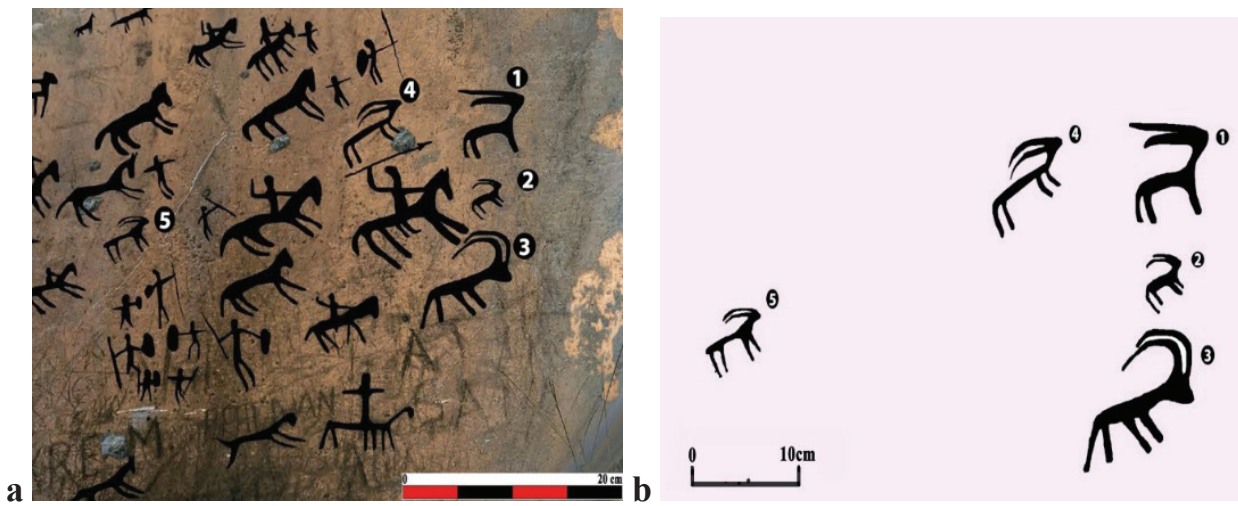

G. 3: a: Çıldır Başköy Kaya Resimleri Dağ Keçisi Motifleri (A. Ceylan Arşivi). b: Çıldır Başköy Kaya Resimleri Dağ Keçisi Motiflerinin Çizimleri (A. Ceylan Arşivi).

Ardahan ili Çıldır Başköy kaya resimlerini incelendiğinde bu resimlerin yakın coğrafyadaki Doyumlu kaya resimleri ile teknik olarak olmasa da tema bakımından benzediği anlaşılmaktadır. İki kaya resim alanında da süvariler ve av törenleri çizilmiştir. Buradaki resimlerin ayrıca Hakkâri/Tırşin yaylası kaya resimleri ile teknik, tematik ve stilistik açıdan benzerlik taşıdığı görülmektedir. Aynı şekilde İran’daki Meşkin kaya resimleri22 ile de teknik ve tematik bakımdan ortaklıklar vardır. Genelde aynı profilden çizilmiş dağ keçisi figürlerinde abartılı boynuz ve dört ayağın belirgin olması öne çıkan unsurlardır. Kafkaslarda Tunç Çağı Gobustan kaya resimleri'23 ve Ermenistan

22 Mohammad Kazemi, vd. "An Introduction of ShikhMedi Newly Found Petroglyphs in Meshginshahr, Northwest Iran,” International Journal of Archaeologyi Special Issue: Rock Art, Handmade Architecture, Historical Archaeology 4/1-1 (2016), 18-22; Ali Binandeh, "Looking at Rock Art in Northwest of Iran," International Journal of Archaeology. Special Issue: Rock Art, Handmade Architecture, Historical Archaeology 4/1-1 (2016), 12-17.

23 Malahat Farajova, "Gobustan Rock Art Cultural Landscape - El paisaje cultural del arte rupestre de Gobustán," Cuadernos De Arte Rupestre 7/2 (2014), 13-232; Abbas Seyidov, “Azerbaycan Halkının Taş Hafızası-Gobustan-Gemikaya Petroglifleri," V. Uluslararası Halk Kültürü ve Sanat Etkinlikleri Sempozyumu (12-14 Ekim 2017 Ankara), (Ankara: Gazi Üniversitesi Yayınları, 2017), 409-418. 
kaya resimleri ${ }^{24}$ de süvari ve av töreni sahnelerini belirtmesi bakımından aynı bağlamda değerlendirilebilir. Genel olarak bu kaya resimlerinde, mekân, stil, çizim tekniği, bağlam ve tema olarak benzerlikler bulunmaktadır. Çevre kültür bölgesiyle yapılan analojik çalışmalar neticesinde şimdilik bu kaya resim alanı Geç Tunç Çağı ile Erken Demir Çağı'na tarihlendirilebilir (G. 4).
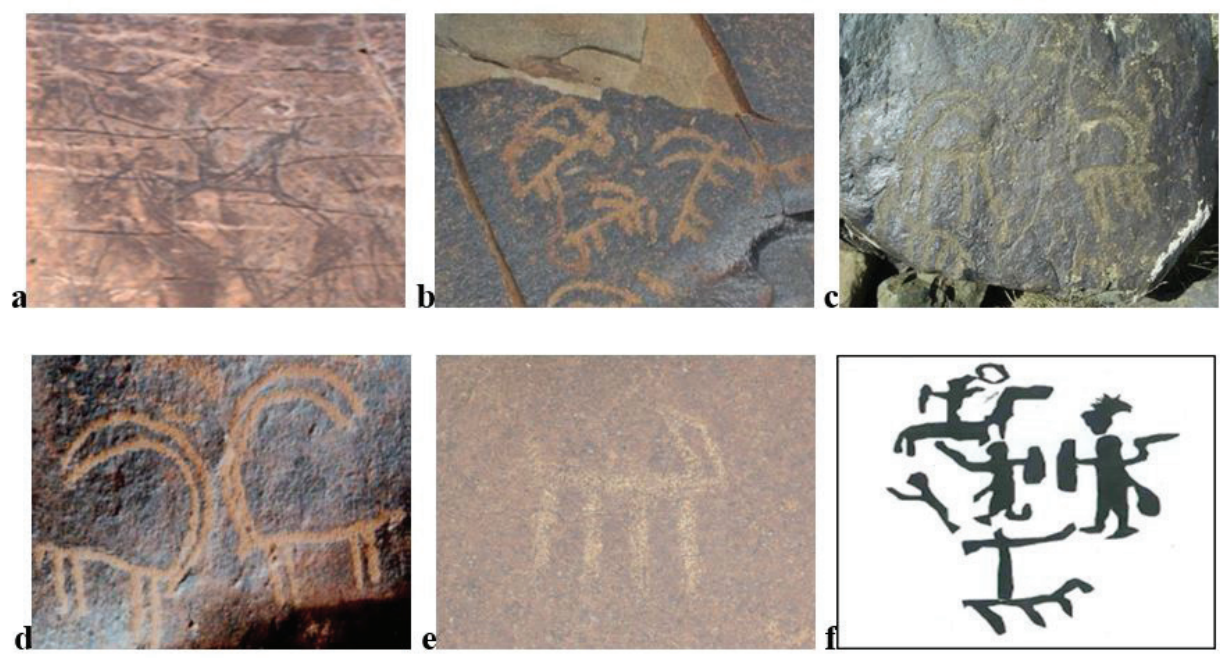

G. 4. a: Doyumlu, elinde mızrağı olan süvari ve av sahnesi. b: Tırşin Yaylası, kazıma tekniği ile çizgisel biçimde profilden çizilmiş dağ keçisi figürleri (Tümer, "Van-Hakkari Dağlık Bölgesi Kaya Resimleri,” 72). c: Gobustan, kazıma tekniği ile çizgisel biçimde profilden çizilmiş dă̆ keçisi figürleri (A Ceylan Arşivi).). d: Ermenistan, kazıma tekniği ile çizgisel biçimde profilden çizilmiş dağ keçisi figürleri (Tokhatyan, "Rock Carvings Of Armenia," 189). e: Meşkin, kazıma tekniği ile çizgisel biçimde profilden çizilmiş dağ keçisi (A Ceylan Arşivi).

f: Asmalıyatak, ellerinde kalkan ve savaş aletleri ile stilize insan figürleri (Somuncuoğlu, Damgaların Göçü Kurgan, 175).

\section{Borluk Vadisi Azat Köyü Kaya Resimleri ${ }^{25}$}

Borluk Vadisi/Azat köyü kaya resimleri, Kars şehir merkezinin 8 km güneybatısında bulunun Azat köyü yakınlarındaki Borluk Vadisi'nde 1830 m rakımda bulunmaktadır (G. 1). Kaya resim alanı Borluk Vadisi'nin kuzey eteğindeki andezit kayalıklar üzerine çizgi-vurgu (gagalama) tekniğiyle çizilmişlerdir ${ }^{26}$.

Panel üzerinde 4 insan, 12 dağ keçisi, 3 dağ koyunu, 4 yaban sığırı, 1 oğlak, 2 domuz ve 1 geyik olmak üzere toplam 28 resim tespit edilmiştir. Ayrıca hayvan olduğu düşünülen ancak tam olarak belirlenemeyen bir çizim daha mevcuttur ${ }^{27}$ (G. 5).

24 Karen Tokhatyan, "Rock Carvings Of Armenı," Fundamental Armenology 2 (2015), 184-204.

$2540^{\circ} 31^{1} 39^{11} \mathrm{~N}-43^{\circ} 07^{1} 20^{11} \mathrm{E}$

26 Bingöl, "Yüzey Araştırmaları Işığında Borluk Vadisi Kayaüstü Resimleri,” 349; Ceylan, "Türk Dünyasından Yeni Kaya Resimleri,” 173.

27 Belli, "Kars - Borluk Vadisi Kayaüstü Resimleri," 11- 22; Bingöl, "Yüzey Araştırmaları Işığında Borluk Vadisi Kayaüstü Resimleri,” 349-355; Özgül, “Orta Asya Kaya Resimleri Işı̆̆ında Kars-Ardahan Kaya Resimlerindeki Av ve Tuzak Sahneleri," 893-911. 


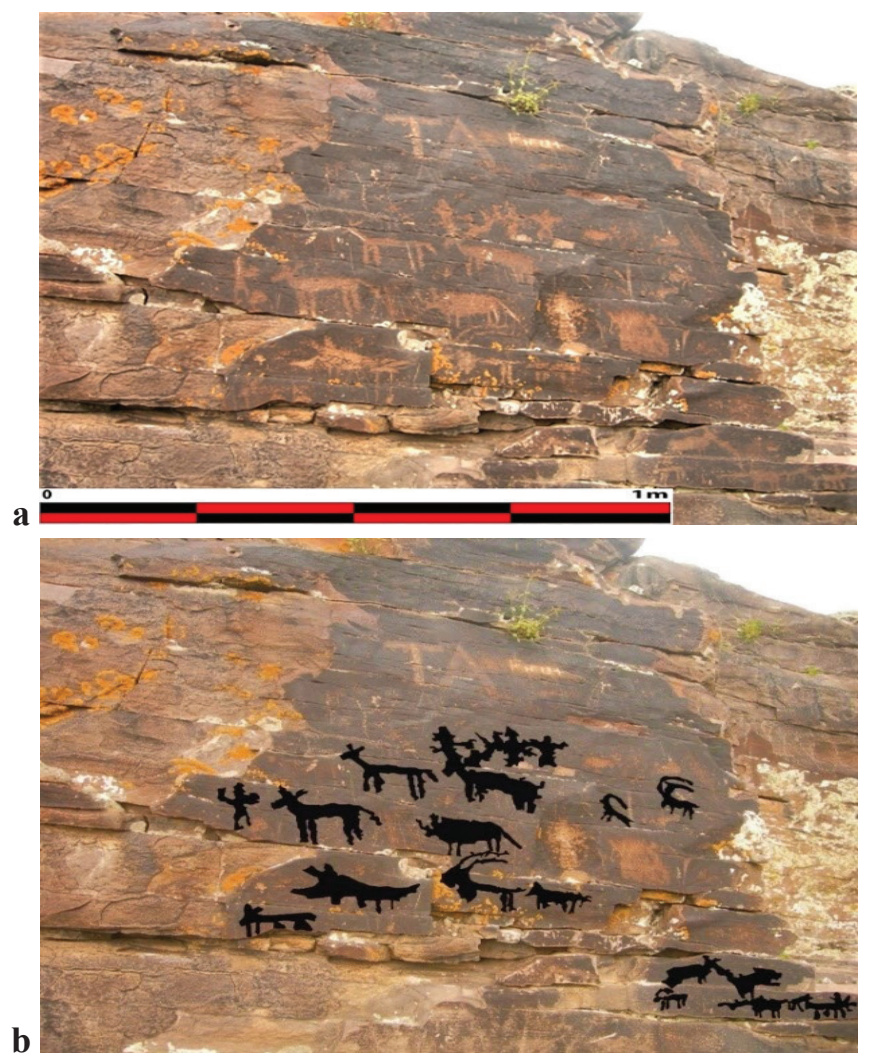

G. 5: a: Borluk Vadisi Azat Köyü Kaya Resimleri Genel Görünümü (A. Ceylan Arşivi).

b: Borluk Vadisi Azat Köyü Kaya Resimleri Genel Çizimi (A. Ceylan Arşivi).

Alanda 13 dağ keçisi figürü bulunmaktadır. Farklı büyüklükte çizilmiş olan dağ keçisi figürleri panonun tamamına serpiştirilmiştir. 1, 2, 3, 4 no.lu figürler gagalama tekniği ile, 5, 6, 7, 8, 9 no.lu figürler ise çizgi-gagalama tekniği ile çizilmişlerdir. Dağ keçilerinin bir kısmı sağ tarafa hareket hâlindeyken bir kısmı da sol tarafa hareket hâlinde resmedilmiştir. Kayanın ortasındaki fiziksel aşınmanın fazla olmasından ve çizilecek alanın azlığından dolayı buradaki keçi figürleri daha küçük boyutlu çizilmişlerdir. Panelin alt tarafindaki vücut hatları belirgin ve oldukça büyük boynuzları ile dikkat çeken 12 no.lu keçi, yaya bir avcı ile fiziksel temas hâlindeyken resmedilmiştir. Avcı elinde yayı germiş ve okunu atmaya hazırlanır vaziyette, (muhtemelen) okunu firlatmış ve keçi figürünü avlamış hâlde çizilmiştir. Yine alt taraftaki keçilerden 12,5 $\mathrm{cm}$ gövdeye $6,5 \mathrm{~cm}$ yüksekliğe sahip olan keçi için A. Bingöl, dişi, onun üzerindeki keçi için ise erkek ayrımını yapmıştır ${ }^{28}$. Dağ keçisi figürleri birbirlerinden bağımsız ve profilden çizilmişlerdir. Keçilerin vücut hatları birbirine göre orantılıdır. Bölgedeki bütün kaya resimlerinde olduğu gibi belirgin unsur, boynuzlardır. Burada da boynuzlar

28 Bingöl, "Yüzey Araştırmaları Işı̆̆ında Borluk Vadisi Kayaüstü Resimleri," 350-351. 
geriye doğru kavisli çizilmiştir. Keçi figürlerinin vücutları dikdörtgen olarak çizilmişken 10 no.lu figürde ise çapraz çizgiler ile gövde oluşturulmuştur. Bu gövde şekli oldukça ender olarak karşımıza çıkmaktadır. Keçi figürlerinin bacakları belirgin bir şekilde çizilmişken bazılarında tırnak da bulunmaktadır. Cinsiyet belirleme açısından önemli olan kuyruk ise, keçilerin birçoğunda mevcuttur. A. Bingöl 13 dağ keçisinin 9'unu erkek, 3'ünü dişi ve birini de oğlak olarak tanımlamıştır ${ }^{29}$. Bize göre de bu tanımlama akla yatkın gibi durmaktadır (G. 6).
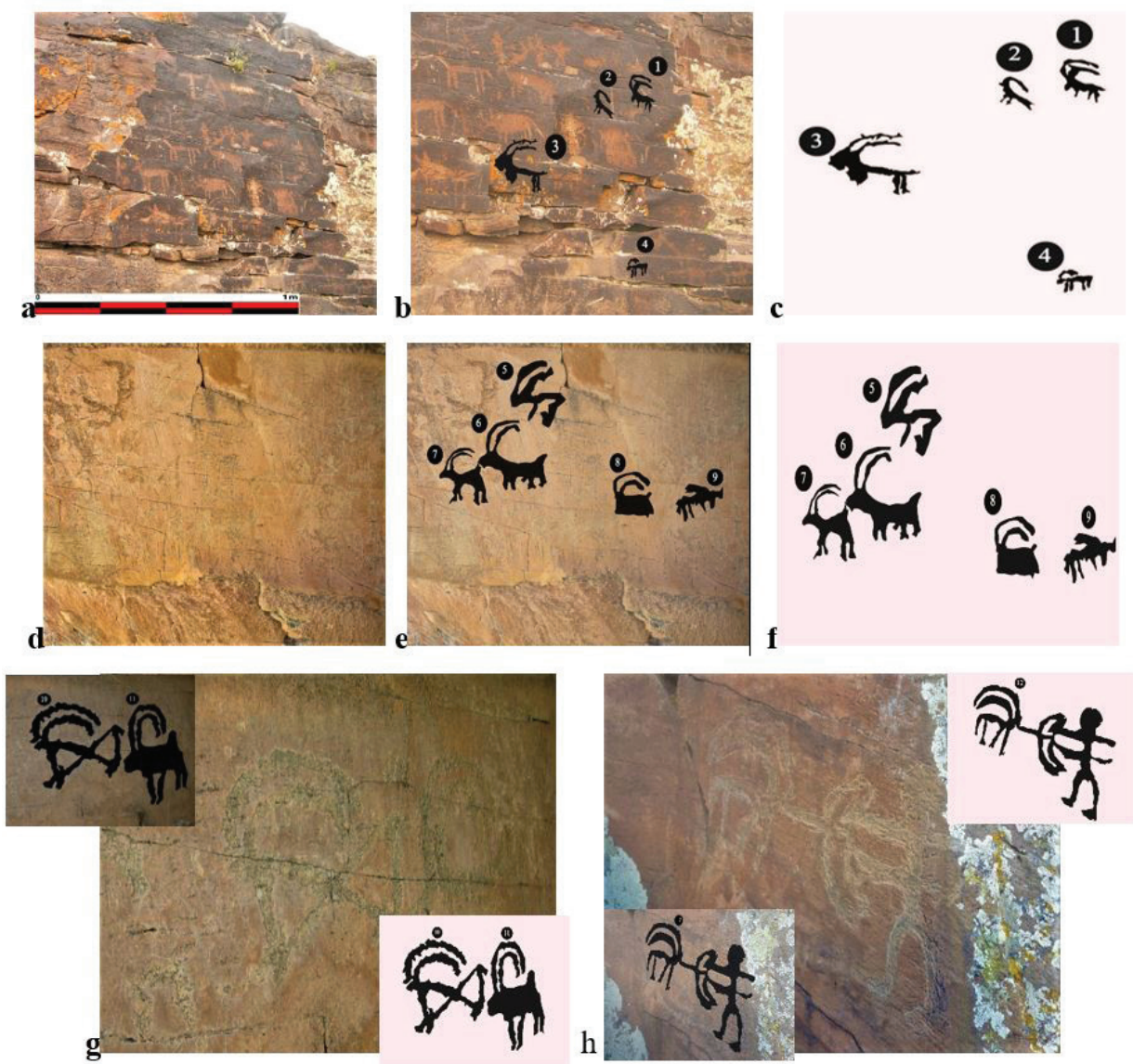

G. 6. a: Borluk Vadisi Azat Köyü Kaya Resimleri Dağ Keçisi Motifleri (A. Ceylan Arşivi).

b, c: Dağ Keçisi Motifi Çizimleri (A. Ceylan Arşivi). d: Dağ Keçisi Motifleri (A. Ceylan Arşivi). e, f: Dağ Keçisi Motifi Çizimleri (A. Ceylan Arşivi). g, h: Dağ Keçisi Motifleri ve Çizimleri (A. Ceylan Arşivi).

Kars ili Borluk Vadisi /Azat Köyü kaya resimlerini incelediğinde, bu resimlerin yakın coğrafyadaki Gevaruk kaya resimleri ile hem teknik hem de kozmik düşünce olarak ortaklıkları olduğu görülmektedir. İki alanda da dağ keçilerinin boynuzlarına

29 Bingöl, "Yüzey Araştırmaları Işığında Borluk Vadisi Kayaüstü Resimleri,” 350. 
asılmış insan figürleri aynı kozmik düşüncenin iki bölgede de bulunduğunu bizlere göstermektedir. Kafkaslarda Ermenistan kaya resimleri ile teknik ve tema benzerlikleri dikkat çeker. Daha uzak coğrafyalar ile mukayese edildiğinde Kırgızistan'daki Saymalıtaş kaya resimleriyle ${ }^{30}$ teknik olarak kısmi benzerlik taşıyan kaya resimleri, tema ve figür bakımından benzerdir. Hem Kafkaslar hem Ermenistan kaya resimleri hem de Saymalıtaş kaya resimlerinde özellikle dağ keçisi motifi ve bireysel av sahnesi çizimleri ortaktır. Bu figürlerde dağ keçileri genelde abartılı boynuzlu bir teke olarak profilden çizilmişlerdir. İnsan figürü ise dağ keçisine nazaran daha küçük boyutludur. Yaptığımız arkeolojik ve analojik çalışmalara göre bu kaya resimleri Geç Tunç Çağı'na tarihlendirilmiştir (G. 7).
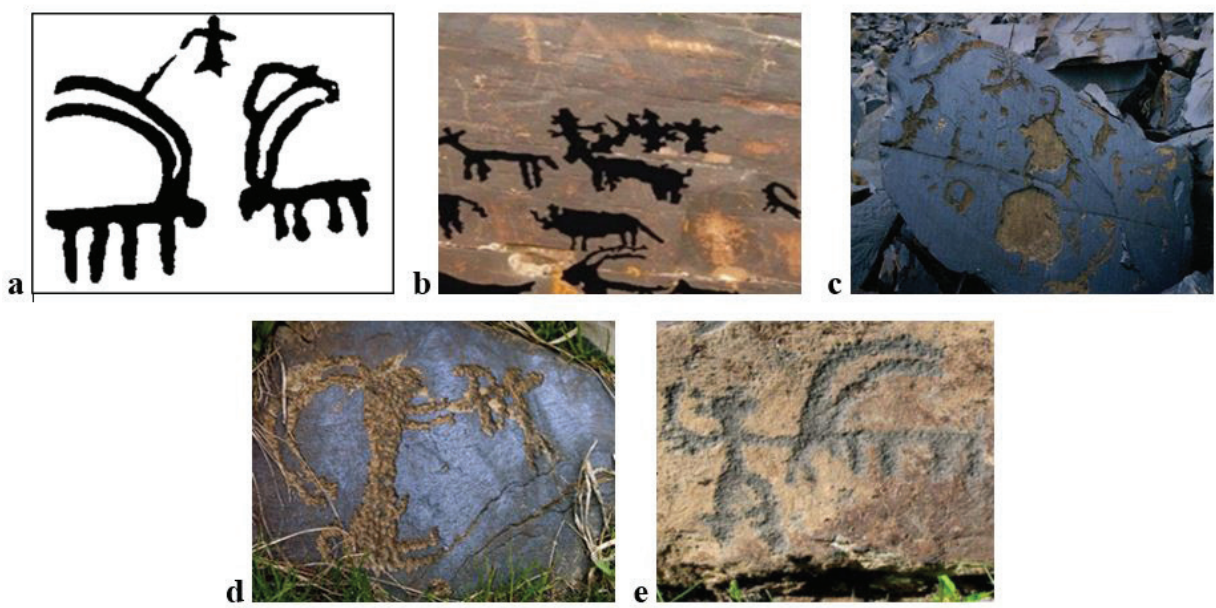

G. 7: a: Gevaruk Yaylası, dağ keçisi figürünün boynuzuna çizilmiş tören hâlindeki insan figürü. (Uyanı, Petroglyphs of South - Eastern Anatolia fig. 31, 7). b: Borluk Vadisi, geyik boynuzuna asılmış tören hâlindeki insan figürleri (A. Ceylan Arşivi). c: Saymalıtaş, gagalama tekniği ile insan, geyik ve dağ keçisi figürleri (Somuncuoğlu, Saymalıtaş: Gökyüzü Atları, 142). d:

Saymalıtaş, gagalama tekniği ile avc1 ve dağ keçisi figürleri (Somuncuoğlu, Saymalıtaş: Gökyüzü Atları, 176). e: Ermenistan, gagalama tekniği ile avc1 ve dağ keçisi figürleri (Tokhatyan, "Rock Carvings Of Armenia," 190).

30 K. I. Tashbayeva, "Petroglyphs of Kyrgystan," Petroglyphs of Central Asia, ed. K. Tashbayeva (Bishkek: International Institute for Central Asian Studies, 2001), 9-80; Bakyt Amanbaeva, Aiday Suleymanova and Chynarbek Zholdoshov, "Rock Art Sites in Kyrgyzstan," Rock Art in Central Asia, ed. Jean Clottes (Paris: International Council on Monuments and Sites, 2011), 43-73. 


\section{Camuşlu Kaya Resimleri ${ }^{31}$}

Camuşlu kaya resim alanı Kars ili, Kağızman ilçesi, Camuşlu köyünün yaklaşık 22 km batısında, Aladağ'ın doğu eteklerinde, Elmalı Yaylası'nda "Yaylaaltı" denilen yerde 3134 m rakımda bulunmaktadır (G. 1). Gagalama ve çizgi tekniğiyle geyik, dăg keçisi, insan ve eşek figürlerinin çizildiği görülmektedir ${ }^{32}$ (G. 8).

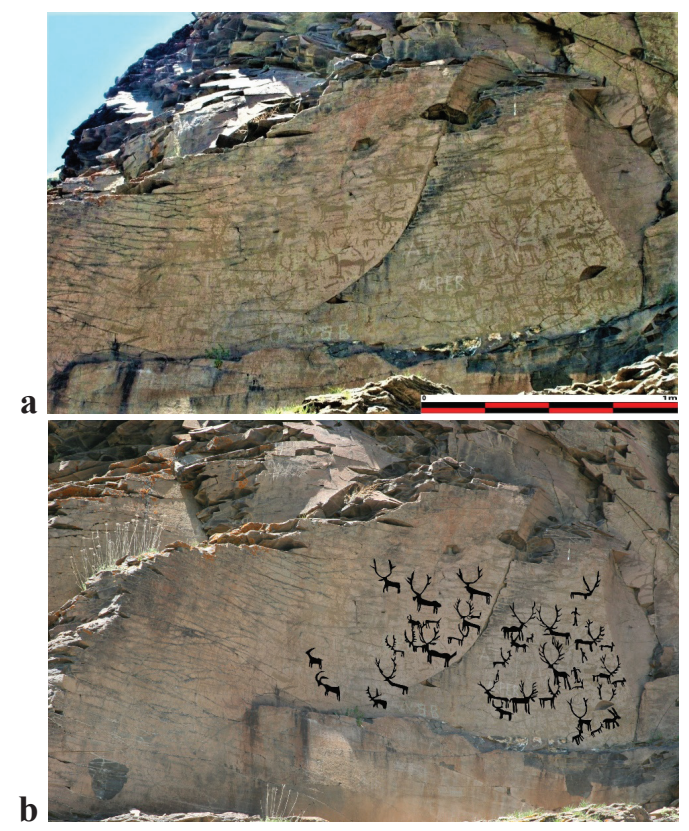

G. 8: a: Camuşlu Kaya Resimleri Genel Görünümü (A. Ceylan Arşivi). b: Camuşlu Kaya Resimleri Genel Çizimi (A. Ceylan Arşivi).

Camuşlu kaya resim alanı geyik ağırlıklı çizimleri ile dikkat çekmektedir. Pastoral temalı olan panelde geyikler, dağ keçileri ve oğlaklar ile birlikte muhtemelen av büyüsü ${ }^{33}$ yapan şamanlar ya da avc1 olarak düşünebilecek insan figürlerinden oluşan bir kompozisyon yer almaktadır. Kökten, panoda 13 kadar dağ keçisi olduğunu belirtmiştir ${ }^{34}$. Kökten'nin 1970’lerde yaptığı incelemelerde tespit ettiği figür sayıları, olumsuz nedenlerden dolayı belirsizleşmiş ya da kaybolmuştur. Bu nedenle yapılan incelemelerde verilen sayılar belirlenememiştir. Camuşlu dağ keçileri, geyikler kadar ince ayrıntılı olmayıp yine de vücut hatları belirgin şekilde çizilmişlerdir. Keçilerin

$3140^{0} 10^{1} 32^{11} \mathrm{~N}-42^{0} 49^{1} 28^{11} \mathrm{E}$

32 Kökten, "Kars Çevresinde Dip Tarih Araştırmaları ve Yazılıkaya Resimleri," 101. Kökten; bu panolardan batıdakini büyük, doğudakini ise küçük pano olarak belirlemiştir. Büyük panoda 100'ün üzerinde hayvan ve insan resmi bulunmaktadır. 54'ü erkek geyik, 11'i dişi geyik, 12'si yavru geyik olmak üzere 77 geyik, 13 dağ keçisi ve çeşitli insan resimleri vardır. Küçük panoda ise oyularak yapılmış 7'si erkek geyik, 3'ü dişi geyik olmak üzere 10 geyik ile 3 insan ve 1 eşek figürü yer almaktadır.

33 Ann Sieveking, Cave Artist (London: Thames \& Hudson, 1979), 55; Mihally Hoppal, Şamanlar ve Semboller; Kaya Resmi ve Göstergebilim, çev. Fatih Sel (İstanbul: Yapı Kredi Yayınları, 2015), 77-78.

34 Kökten, "Kars Çevresinde Dip Tarih Araştırmaları ve Yazılıkaya Resimleri,” 104. 
boynuzları mevcut olup dişi ve oğlaklarda boynuzlar daha küçüktür. Muhtemelen 1, 2, 4, 6 no.lu keçiler oğlak veya dişi olarak verilmek istenmiştir. Dikdörtgenimsi vücuda sahip olan keçi figürleri gagalama tekniği ile çizilmişlerdir. Bazılarında kafa belirtilmişken, bazılarında bu belirsizlik boynuzlar ile giderilmiştir. Keçilerin dört bacağı da belirgin olarak çizilmiştir. Bazılarında tırnak belirtisi vardır. Keçi figürleri farklı yönlere doğru ve geyiklere göre küçük resmedilmişler (G. 9).
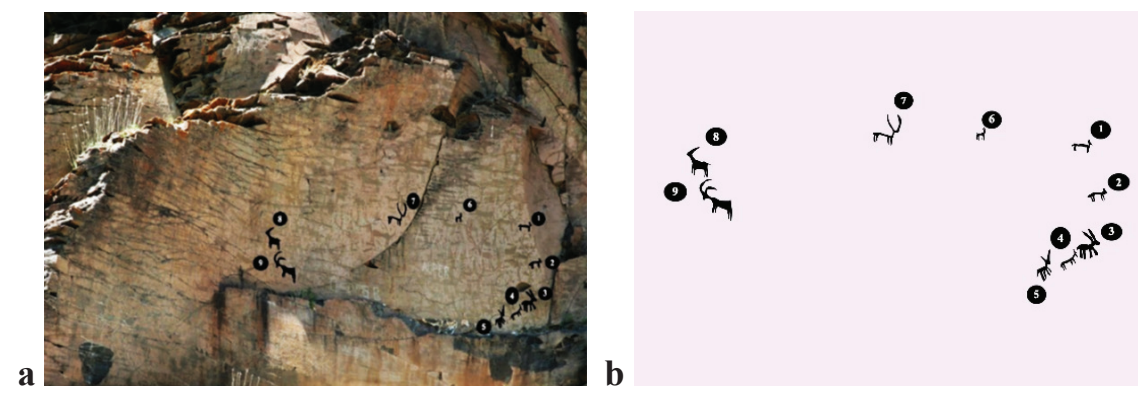

G. 9: a: Camuşlu Kaya Resimleri Dağ Keçileri (A. Ceylan Arşivi). b: Camuşlu Kaya Resimleri Dağ Keçisi Motiflerinin Çizimleri (A. Ceylan Arşivi).

\section{Digor/Dolaylı Kaya Resimleri ${ }^{35}$}

Digor/Dolaylı resim alanı ${ }^{36}$ Kars ili, Digor ilçesi, Dolaylı köyünün 2 km kuzeydoğusundaki kayalıklar üzerinde 1570 m rakımda bulunmaktadır (G. 1). Resim ala$\mathrm{n}$, birinci ve ikinci resim alanı olarak incelenmiştir. Birinci resim alanında üç pano tespit edilmiştir. Birinci panoda; avc1, tuzak, tuzağa düşmüş ancak belirlenemeyen bir hayvan ve dağ keçisi bulunmaktadır. İkinci pano birinci panonun doğusunda parçalanmakta olan kaya üzerinde yer almaktadır. Burada dört adet dağ keçisi motifi vardır. Dağ keçisi figürlerinin ikisi sırt sırta vermiş ve hareketli tarzda resmedilmiştir. Boynuzları oldukça belirgindir. Üçüncü pano; dağ keçileri ile elinde silahı ve kalkanı bulunan avcı ve tören sahnesini içermektedir. Dağ keçileri panonun değişik yerlerinde bulunmaktadır. Buradaki dağ keçilerinden birinde süvarinin olması dikkat çekmektedir. Saymalıtaş (G. 12e), Çolpan-Ata (G. 12f) ve Anadolu (G. 10, G. 12g) kaya resimlerinde nadir de olsa görülen bu çizim, kişinin dünyalar arasındaki gezintisini ifade etmektedir. Panonun üst kısmında bir tören sahnesi işlenmiştir. İnsanlar burada ellerini açmış bir şekilde tören yaparken çizilmişlerdir. Taştaki tahribat yüzünden bu törene katılan insanların sayısı tam olarak belirlenememiştir. Panoda at üstünde geriye doğru ok atan süvari çizimi dikkat çeken başka bir motiftir. Panodaki üç güneş kursu ise bizlere Saymalıtaş’ın Tunç dönemi güneş kurslarını hatırlatmaktadır.

İkinci alandaki resimler, diğer alanlar gibi aşınmış bir kayaya işlenmiştir. İşleme özellikle kayanın düz yüzeylerine uygulanmıştır. Alan iki sıra hâlinde dağ keçisi fi-

36 A. Ceylan tarafından 2017 yılında keşfedilen Dolaylı kaya resimleri 2018 yılında TTK Kongresi'nde bildiri olarak sunulmuştur. 2019 yılında kaya resimleri tarafimızdan tekrar incelenmiştir. 
gürlerini içermektedir. Dağ keçileri hareketli bir vaziyette çizilmiştir. Panonun batı uç kısmındaki figür oldukça dikkat çekicidir. Bu figür Hakkâri taş heykelleri ${ }^{37}$ ve Horasan-Hasanbey taş heykeline ${ }^{38}$ benzemektedir. Bu alan, işleme tekniği açısından birinci alandan farklidir ${ }^{39}$ (G. 10).
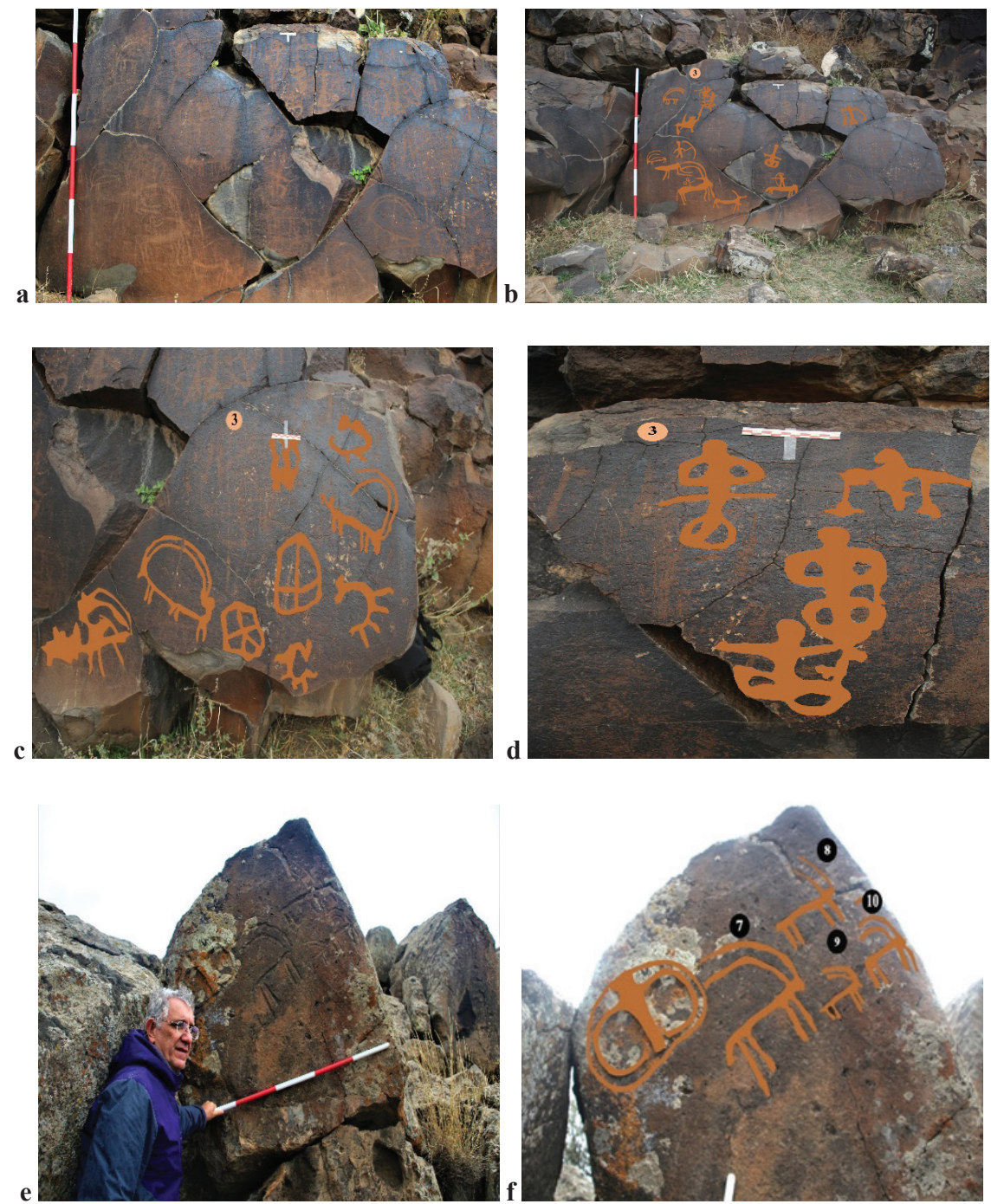

G. 10: a, e: Digor/Dolaylı Kaya Resimleri Genel Görünümü (A. Ceylan Arşivi). b, c, d, f: Digor/Dolaylı Kaya Resimleri Genel Çizimleri (A. Ceylan Arşivi).

37 Veli Sevin ve Aynur Özfirat, "Hakkâri Stelleri: ve Doğu Anadolu'da İlk Çobanlar,” Belleten LXV/243 (2001), 501- 518; Veli Sevin, Hakkâri Taşları Çıplak Savaşçıların Gizemi (İstanbul: Yapı Kredi Yayınları, 2005), 15-114; Veli Sevin, Hakkâri Taşları II Gizemin Peşinde (Ankara: Türk Tarih Kurumu Yayınevi, 2015), 1-110.

38 Ceylan, Doğu Anadolu Araştırmaları Erzurum-Erzincan-Kars-Iğdır 2008-2014, 300-301; Nezahat Ceylan ve Yavuz Günaşdı, "Doğu Anadolu'da Bulunan Bazı Taş Heykellerin Orta Asya'daki Örnekler İle Mukayesesi," 16. Uluslararası Türk Dünyası Sosyal Bilimler Kongresi (4-6 Eylül 2018 Çimkent), (İstanbul: Türk Dünyası Araştırmaları Vakfı Yayınları, 2018), 633-646.

39 Ceylan, “Doğu Anadolu’da Erken Dönem Türk İzleri III Kars-Digor (Dolaylı) Kaya Resimleri”. 
Alanda 17'nin üzerinde dağ keçisi figürü tespit edilmiştir. Birinci alandaki dağ keçisi figürleri çizgisel kazıma yöntemi ile çizilmişlerdir. Buradaki dağ keçilerinin gövdeleri diğer alanlarla kıyaslandığında daha ince şekilde ama yine dikdörtgenimsi vaziyettedir. Boynuzlar ise oldukça abartılı ve geriye doğru kavislidir. Bacak detayları bütün keçilerde vardır ancak tırnak işlenmemiştir. 5 ve 6 no.lu keçiler burada dikkati çekmektedir. İki dağ keçisinin arka arkaya bitişik vaziyette çizilerek boynuzlarının birbirine değecek kadar uzun ve kavisli olması sanatçı tarafindan belirtilmek istenmiştir. Boynuz büyüklüğü ve kavisli olması bunların teke olduğunu göstermektedir. İkinci alandaki 7, 8, 9, 12 no.lu figürler ise birinci alandan farklı olarak derin çizgilerle stilize olarak çizilmişlerdir. Buradaki keçi figürlerinin hepsi aynı yöne doğru hareketli olarak resmedilmiştir. Keçilerin hareket yönünün tersinde bulunan Hakkâri ve Horasan taş heykellerine benzetebileceğimiz, büyük ihtimalle insan figürü olarak düşündüğümüz figürden kaçtıkları düşünülebilir. Keçilerin figürlerinin hepsinde boynuz abartısı vardır. Bu kaya resim alanında kuyruk yoktur. Bacaklar ise çizgisel olarak belirtilmiştir (G. 11).

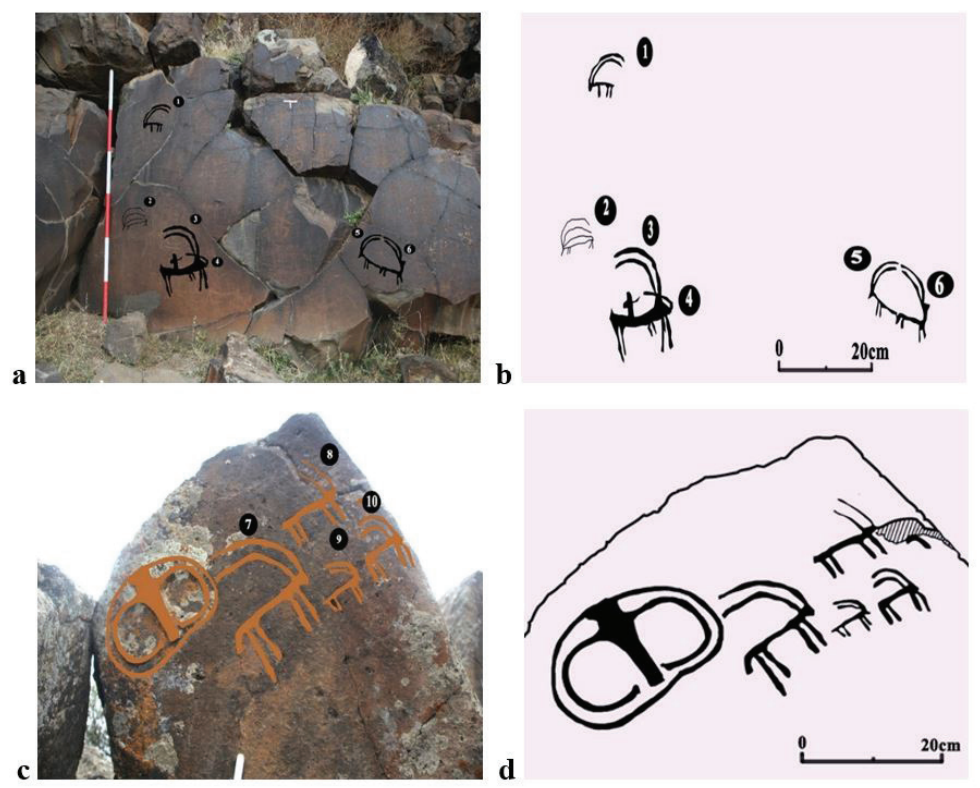

G. 11: a, b, c, d: Digor/Dolaylı Kaya Resimleri Dağ Keçisi Motifleri Çizimi (A Ceylan Arşivi).

Kars ili Digor ilçesi Dolaylı kaya resimlerini Anadolu'da Karaboncuk kaya resimleri ile teknik ve tematik; Dereler Mağarası kaya resimleri, Tırşin Yaylası ve DeliklikayaGölgelidere kaya resimleri ile de teknik ve figür olarak benzerdir. İkinci alanda bulunan ve keçileri gözetleyen insan tasviri ve Horasan-Hasanbey heykeli neredeyse aynıdır. Kafkaslarda, Gobustan kaya resimleri ile Orta Asya'da Saymalıtaş, Çolpan-ata kaya resimleri ile mekân, stil, çizim tekniği, bağlam ve tema olarak benzerlikler bulunmaktadır. Yapılan analojik çalışmalar sonucunda Dolaylı kaya resimleri, Geç Tunç Çağı'na 
tarihlendirilmiştir. Digor kaya resimleri, Karaboncuk, Çolpan Ata, Meşkin ve Saymalıtaş kaya resimleri arasında en dikkat çeken ortak figürler abartılı boynuzlu dağ keçisi üzerinde ayakta durur vaziyette ok atan avcı figürüdür. Yine yan profilden çizilmiş abartılı boynuzlu dağ keçileri bu merkezlerde oldukça yoğundur (G. 12).
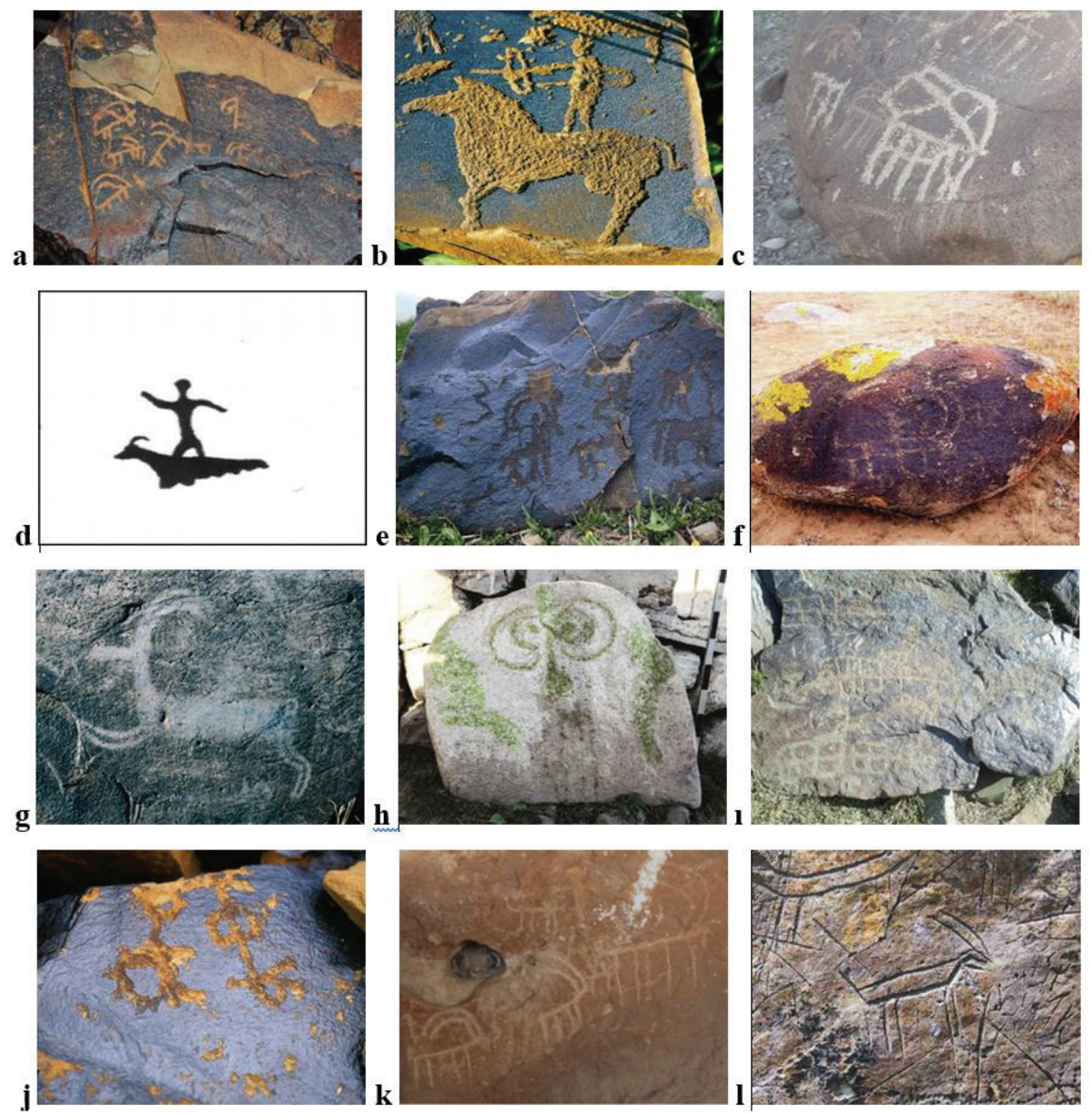

G. 12. a: Tırşin yaylası, çizgisel kazıma tekniği ile dağ keçisi figürleri. (Tümer, "Van-Hakkari Dağlık Bölgesi Kaya Resimleri," 54). b: Saymalıtaş, at üzerinde ayakta ok atar vaziyette avcı.

(Somuncuoğlu, Saymalıtaş: Gökyüzü Atları, 173) c: Meşkin, sırt sırta vermiş boynuzları birbirine ulaşmış iki dağ keçisi figürü (A. Ceylan Arşivi). d: Gevri Bıhıri Mevki Kaya Resimleri, dağ keçisine figürüne binmiş insan tasviri. (Belli, "Van Bölgesi'ndeki Yeni Boyalı Mağara Resimleri." 40) e: Saymalıtaş, dağ keçisi figürüne binmiş insan tasviri. (Somuncuoğlu, Saymalıtaş: Gökyüzü Atlarl, 138). f: Çolpan-Ata, dağ keçisi figürüne binmiş insan tasviri. (Somuncuoğlu, Sibiryadan Anadolu'ya Taştaki Türkler, 138). g: Karaboncuk Kaya Resimleri, dağ keçisi figürüne binmiş insan tasviri (A. Ceylan Arşivi). h: Horasan - Hasanbey Heykeli, insan yüzü tasviri (A. Ceylan Arşivi). ı: Gobustan, damgalar (A. Ceylan Arşivi). j: Saymalıtaş, damgalar. (Somuncuoğlu, Saymalıtaş: Gökyüzü Atlarl, 511). k: Batman Dereler mağarası, oyma tekniği ile profilden çizilmiş stilize dağ keçileri (Soydan ve Korkmaz, "Batman’da Yeni Bir Keşif: Deraser (Arık) Mağara Resimleri,” 685). I: Deliklikaya-Gölgelidere, oyma tekniği ile profilden çizilmiş stilize dağ keçisi figürü. (Somuncuoğlu, Damgaların Göçü Kurgan,134) 


\section{Geyiklitepe Kaya Resimleri ${ }^{40}$}

Geyiklitepe kaya resim alanı, (G. 1) Kars ili, Kağızman ilçesi, Şaban köyünün $5 \mathrm{~km}$ güneydoğusunda, Çallı köyünün $3 \mathrm{~km}$ kuzeybatısında ve Şaban köyüne bağlı Seksen (Sakasen) Mahallesi'nin $2 \mathrm{~km}$ doğusunda 2247 m rakımda bulunmaktadır. Panolarda çizgi tekniği ile ceylan, geyik, köpek, deve, tilki, kuş ve dağ keçisi motifi görülmektedir. Ayrıca resim alanında tuzak sahnesi, hayat ağacı ve runik harfler de dikkat çekmektedir ${ }^{41}$ (G. 13).

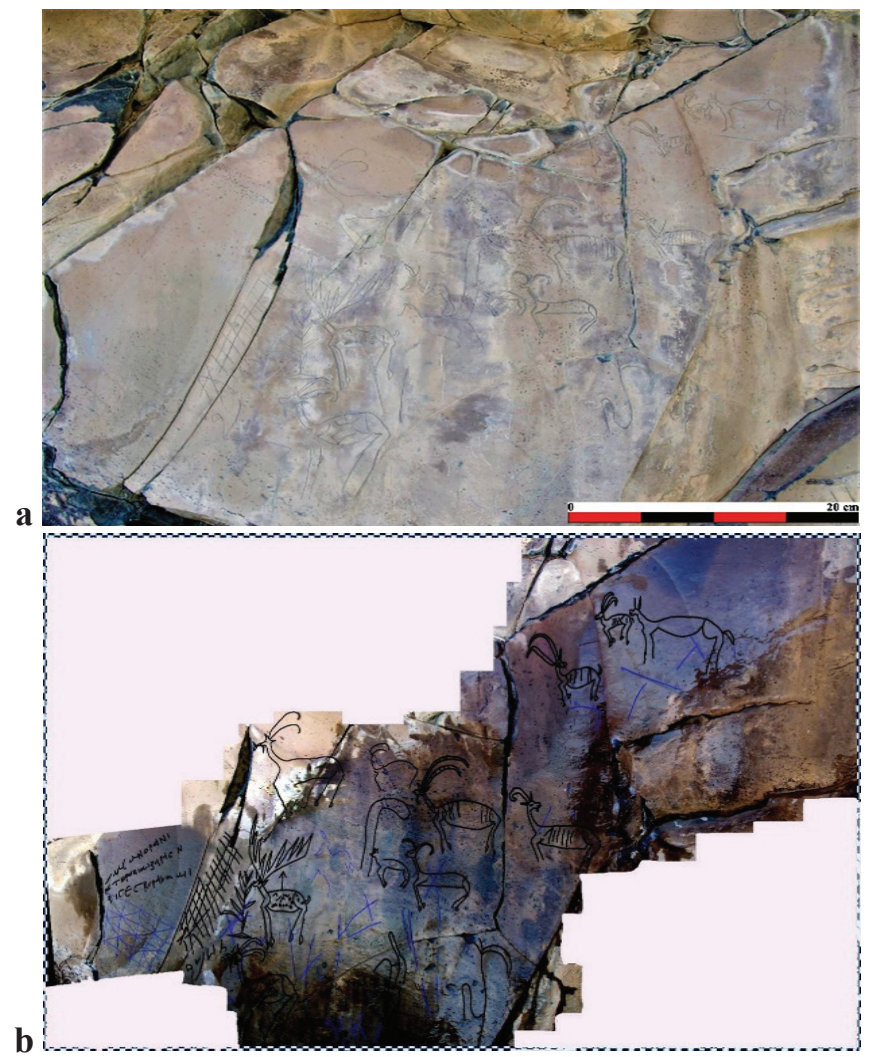

G. 13: a: Geyiklitepe Kaya Resimleri Genel Görünümü (A. Ceylan Arşivi). b: Geyiklitepe Kaya Resimleri Genel Çizimi (A. Ceylan Arşivi).

Resim alanında 13 adet keçi figürü tespit edilmiştir. Bu figürler profilden çizgi tekniği ile çizilmişlerdir. Figürlerin vücutları gerçek keçileri andırır biçimde ovaldir. $\mathrm{Bu}$ ovalliği verebilmek için bazı keçilerde omurgadan göbeğe inen hafif açılı çizgiler yapılmıştır. Yine figürlerin sakalları belirtilmiştir. Keçi figürlerinin dört bacağı da

$4040^{0} 15^{\mathrm{I}} 43^{\mathrm{II}} \mathrm{N}-43^{0} 08^{\mathrm{I}} 20^{\mathrm{II}} \mathrm{E}$

41 Ceylan, "Geyiklitepe Kaya Resimleri ve Runik Yazıtları,” 85-96; Ceylan, "Türk Dünyasından Yeni Kaya Resimleri," 177; Özgül, "Orta Asya Kaya Resimleri Işığında Kars-Ardahan Kaya Resimlerindeki Av ve Tuzak Sahneleri,” 898-899. 
çizilmiş ve baldır kısımları belirtilmiş ve tırnak uzantısı da eklenmiştir. Keçilerin kuyrukları ise genelde dik vaziyettedir. Keçilerin boyun uzantısı belirtilmiş akabinde kafatası ile devam etmiş ve üzerinde boynuzlar arkaya doğru oldukça eğimli olarak çizilmiştir. Bazı boynuzlarda detay olarak boğumlar da belirtilmiştir. Keçi figürlerinin bazıları ise arkaya bakar vaziyettedir. Panonun alt tarafındaki bir keçi figürü ise yatar vaziyette bütün ayrıntıları ile çizilmiştir (G. 14).
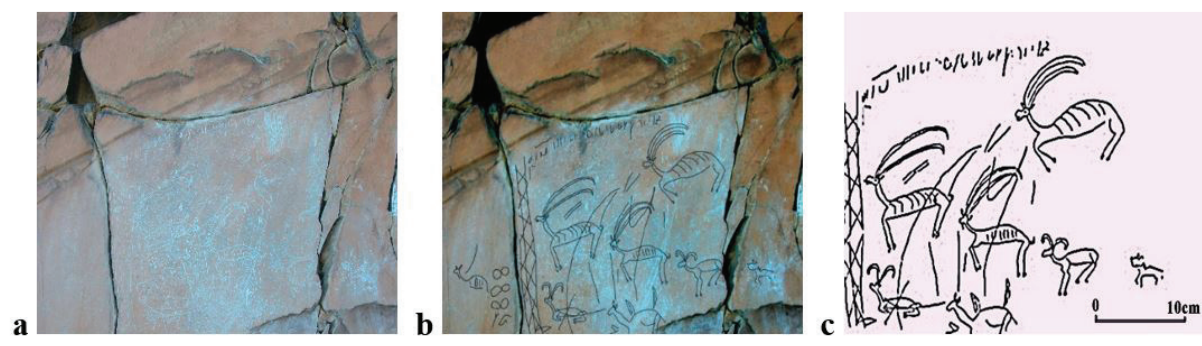

G. 14: a: Geyiklitepe Kaya Resimleri Dağ Keçisi Motifleri (A. Ceylan Arşivi).

b, c: Geyiklitepe Kaya Resimleri Dağ Keçisi Motifi Çizimleri (A. Ceylan Arşivi).

Kars ili Kağızman ilçesi Geyiklitepe kaya resimlerinin yakın coğrafyadaki Erzincan/ Dilli vadisi resimleri ile stil, çizim tekniği, bağlam ve tematik bakımdan benzerlikler taşıdığı görülmektedir. Dağ keçilerinin hemen üstündeki runik harflerin varlığı Anadolu'daki bu tarzın ender örneklerinden birini sunmaktadır. Bu şekilde runik harfler ile aynı paneldeki dağ keçisi figürleri ve tuzak sahnelerine Anadolu'da Esatlı'da, Kabaoyukta ve Gülnar kaya resimlerinde; uzak coğrafyalarda ise Gobi Çölü kaya resimlerinde ve Biçiktu Boom kaya resimlerinde rastlanmaktadır. Runik yazının ortaya çıkışı ile yayılım coğrafyasına ${ }^{42}$ bakıldığında ayrıca bu resimler işleniş tekniği ve tematik bakımdan incelendiğinde, MS 1. binin içinde yapıldığı düşünülebilir. Ayrıca resim alanının hemen yakınında bulunan "Sakasen Yerleşmesi” akıllara İskitleri getirmektedir" ${ }^{43}$. Bölge hakkında önemli bilgiler veren Antik kaynaklardan Ksenephon Çoruh Irmağı’ndan geçerken şu bilgileri verir; "Bundan sonra dört plethron (1 plethron: 100 ayak: 29,6 m) genişliğinde Harpasos (Çoruh) nehrine kadar ilerlediler. Buradan da Skythenler'in memleketine girerek, bir ovada dört günde yirmi parasang (1 fersah: 5,5 km) gittiler ve

42 Viladimir A. Livşıts, "Eski Türk Runik Yazısının Ortaya Çıkışı Üzerine,” çev. S. Gömeç ve T. Ölçekçi, Ankara Üniversitesi Dil ve Tarih-Coğrafya Fakültesi Dergisi 20/31 (2000), 37-50; Risbek Alimov, "Kırgızistan'da Yeni Bulunan Runik Harfli Eski Türk Yazıtları Hakkında Ön Bilgiler," Türk Dili Araştırmaları Yıllı̆̆ı-Belleten 48 (2000), 5-10; İsmail Doğan, Doğu Avrupa'daki Göktürk (Runik) Ișaretli Yazıtlar (Ankara: Türk Dil Kurumu Yayınları, 2002), 1-245; İsmail Doğan, Kafkaslardaki Göktürk (Runik) İşaretli Yazıtlar (Ankara: Türk Dil Kurumu Yayınları, 2019), 1-244; Altay Amanjolov, “Ataların Sözleri,” Erdem 5/15 (1989), 797-802; Erhan Aydın, "Eski Türk Yazıtlarının Yapılış ve Dikilişleri Üzerine," Gazi Üniversitesi Türkiyat Araşstırmaları Dergisi 1 (2007), 149-158.

43 Sakasen Kalesi ve bölgedeki diğer toponomiler hakkında detaylı bilgi için bk. Oktay Özgül, "Çoruh ve Kür Vadisinde Kimmer-İskit Yer Adları." Ardahan Üniversitesi İnsani Bilimler ve Edebiyat Fakültesi Dergisi $B E L G \ddot{U} 2$ (2015), 159-179. 
köylere vardılar. Burada üç gün kalarak erzak tedarik ettiler"44. Herodotos ise İskitlerin savaşçı kimliklerinden, Anadolu'daki faaliyetlerinden ve aynı zamanda Anadolu'da 28 yıl kaldıklarından bahsetmektedir ${ }^{45}$. Antik kaynaklarla beraber bölgedeki arkeolojik bulgular bu görüşümüzü desteklemektedir ${ }^{46}$ (G. 15).
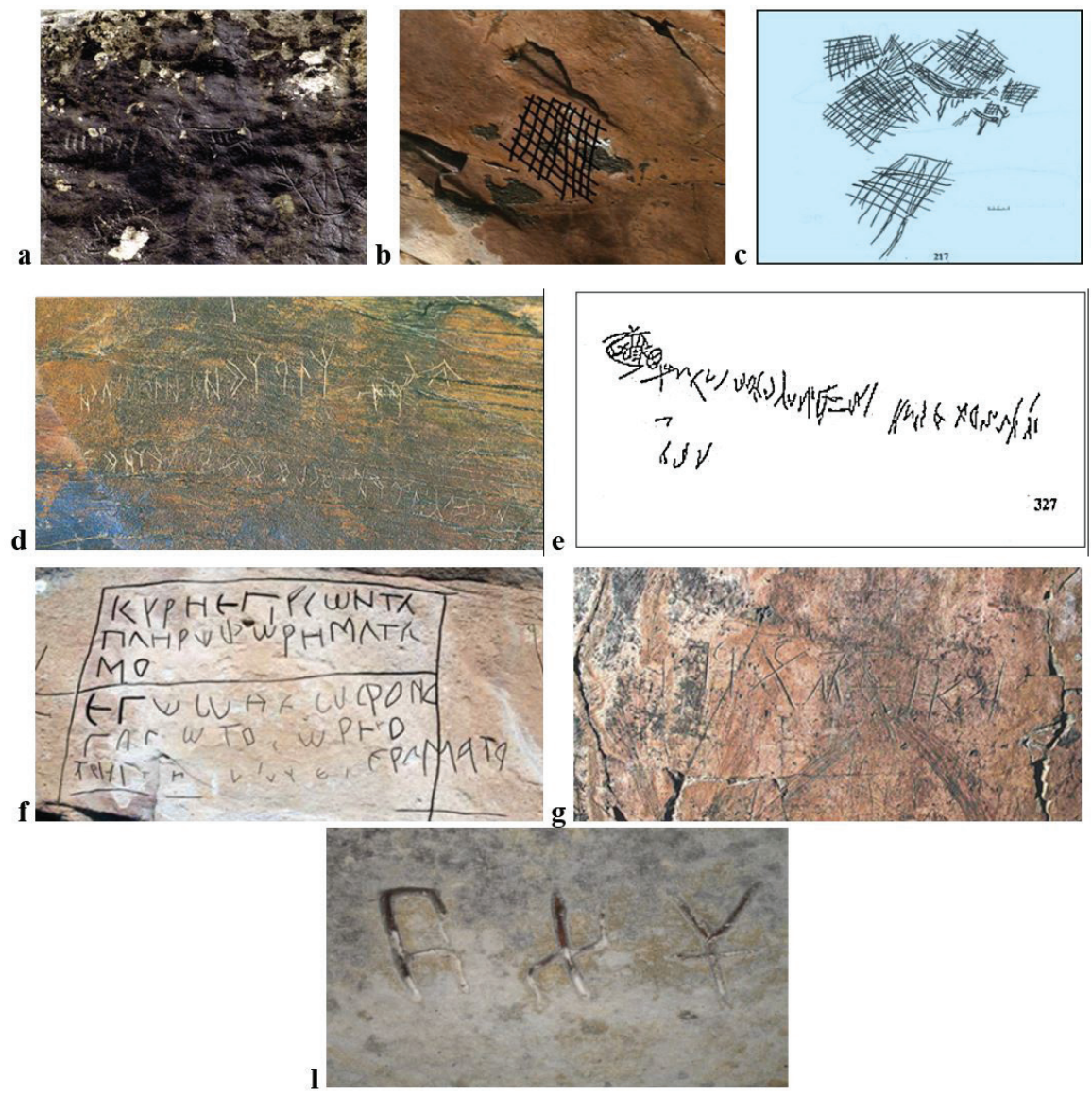

G. 15: a: Dilli Vadisi, çizgi tekniği ile çizilmiş, vucut ovalliği verilmiş dağ keçisi figürü (A. Ceylan Arşivi). b: Dereiçi Kaya Resim Alanı, tuzak motifi (A. Ceylan Arşivi). c: Biçiktu Boom, tuzak Motifi. (Martinov, Altay Kaya Resimleri Biçiktu-Boom, fig. 217). d: Gobi Çölü Kaya Resimleri, Runik yazı (Somuncuoğlu, Sibiryadan Anadolu'ya Taştaki Türkler, 101). e: Biçiktu Boom kaya resimleri, Runik Yazı (Martinov, Altay Kaya Resimleri Biçiktu-Boom, fig 327). f: Esatlı yazıtları, runik yazı, (Saltoğlu, Unutulmuş Bir Geçmişten Oğuz-Kıpçak Sesler - Esatlı Yazıtları I-II, 256.). g: Kabaoyuk Kaya resim Alanı, runik yazıt. (Somuncuoğlu, Damgaların Göçü Kurgan, 406.) 1. Gülnar, Runik yazıt (Şahin, “İçel/Gülnar’da Eski Türklere Ait Yeni Tespit Edilmiş Epigrafik Belgeler: Tanıtımı Ve Ön Değerlendirmesi,” 292).

44 Ksenophon, Anabasis (Onbinlerin Dönüşü). çev. Tanju Gökçöl (İstanbul: Hürriyet Yayınları 1998), 141. 45 Herodotos, Herodotos Tarihi. çev. Müntekim Ökmen (İstanbul: Remzi Kitabevi 1991), 203.

46 İlhami Durmuş, “Anadolu'da Kimmerler ve İskitler," Belleten LXI (1997), 273-286; Oya San, "Bazı Bulgular Işı̆ı̆ında Anadolu'da Kimmer ve İskit Varlığı Üzerine Gözlemler,” Belleten C: LXIV/1 (1998), 1-21; Oktay Özgül, "Erzurum ve Çevresinde Erken Dönem Türk İzlerine Ait Yeni Bulgular," Atatürk Üniversitesi Edebiyat Fakültesi Dergisi 65 (2020), 219-245. 


\section{Kurbanağa Kaya Resimleri ${ }^{47}$}

Kurbanağa kaya resimleri, Kars ili, Kağızman ilçesi, Camuşlu köyünün 6 km güneybatısında Aladağ'ın doğusunda Tombul Tepe Mevkii'nde 1660 m rakımda bulunmaktadır (G. 1). Yazılıkaya resim alanının 6 km güneyinde yer alan Kurbanağa kaya resim alanı, ağzı güneye bakan bir mağara içine ve çevresine çizilen kaya resimlerini barındırmaktadır. Kaya resimleri mağaranın dış yüzeylerine ve iç kısmındaki tavana çizilmiştir. Genelde çizgi tekniği kullanılmışken resimlerde az da olsa gagalama tekniği görülmektedir. Resimler genelde keçi figürü ağırlıklı olarak çizilmişlerdir. Alanda kazıklı tuzaklar ve ağ figürleri de mevcuttur ${ }^{48}$ (G. 16).

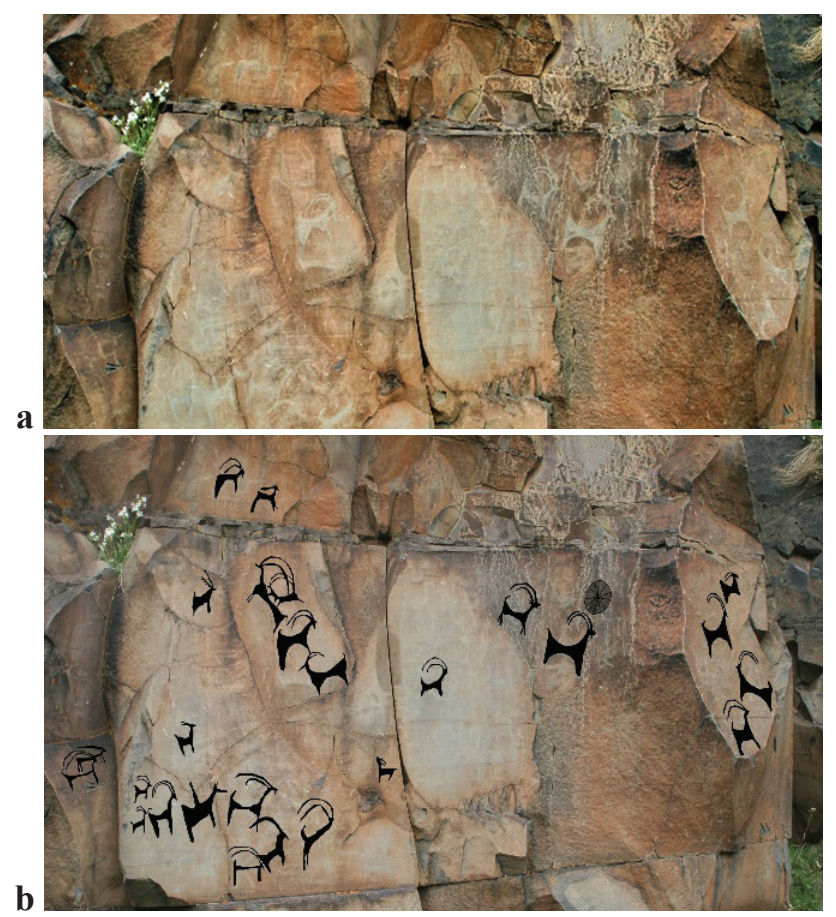

G. 16: a: Kurbanağa Kaya Resimleri Genel Görünümü (A. Ceylan Arşivi). b: Kurbanağa Kaya Resimleri Genel Çizimi (A. Ceylan Arşivi).

Dağ keçisi figürü açısından son derece zengin olan kaya resimleri genelde çizgi tekniği ve kazıma şeklinde profilden çizilmiştir. Mağara içinde bulunan figürlerden bazılarında gagalama tekniği görülmektedir. 50'nin üzerinde dağ keçisi figürü incelendiğinde hemen hepsinin tek bir sanatçının ya da tek bir ekolün elinden çıktığı

$4740^{0} 12^{\mathrm{I}} 12^{\mathrm{II}} \mathrm{N}-42^{0} 56^{\mathrm{I}} 02^{\mathrm{II}} \mathrm{E}$

48 Mağarada 1969 yılında İ. K. Kökten yönetiminde 3.5 x 8 m boyutlarında bir deneme açması yapılmıştır. Kökten'in verdiği bilgiye göre üst bölümde İlk Tunç Çağı çanak-çömleğin bulunduğu, alt kısımda da Üst ve Orta Paleolitik Çağ taş aletleri ve bu çağın ocak yerleri ortaya çıkarılmıştır. Kökten, "Yazılıkaya'da ve Kurbanağa Mağarasında (Kars-Çamuşlu) Yeni Bulunan Dip Tarih Resimleri," 2-16; Savaş Harmankaya ve Oğuz Tanındı, Türkiye Arkeolojik Yerleşmeleri (İstanbul: Ege Yayınları, 1996), Kurbanağa. 
görülebilmektedir. Keçilerin tamamında vücut hatları belli olup gövdenin orta kısımlarından içeriye basık olması dikkat çekmektedir. Figürler yan profilden çizildiği için bacaklar tek bir bacak gibi görülmektedir. Ayaklarda tırnak belirtilmemiştir. Genelde boyun uzunluğu verilen keçi figürlerinin kafa yapıları belirgindir. Ayrıca 1 ve 2 no.lu figürlerde görüldüğ̈̈ gibi sakal da bulunmaktadır. Boynuzlar geriye doğru kavisli ve 1 ve 6 no.lu çizimlerde de görüldüğü gibi oldukça abartılıdır. Nitekim panonun üst sol kısmında arka arkaya duran iki keçinin boynuzları birlikte 180 derecelik bir daire oluşturarak birliktelik sağlamışlardır. Boynuzlar profil açısı farkından dolayı bazen tek bazen de çift olarak düşünülmüştür. Keçilerin bazılarında hareket algısı gözlemlenmektedir. Ayrıca keçi figürlerinin her biri farklı yöne doğru çizilmişlerdir (G. 17).
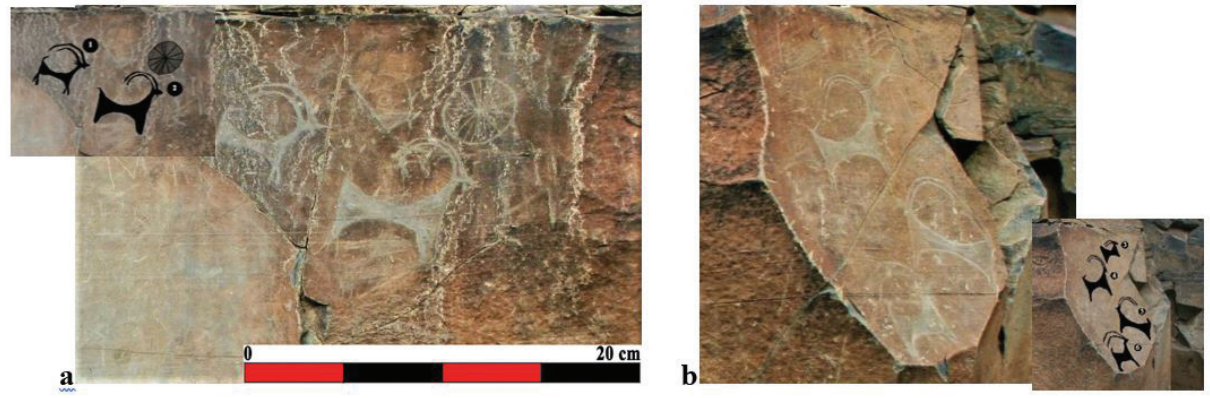

G. 17: a, b: Kurbanağa Kaya Resimleri Dağ Keçisi Motifi ve Çizimleri (A. Ceylan Arşivi).

Kars ili Kağızman ilçesi Kurbanağa kaya resimlerinin Anadolu'da Kaynak Köyü kaya resimleri ve Kırgızistan'da Saymalıtaş kaya resimleriyle mekân, stil, çizim tekniği, bağlam ve tema olarak benzerlikleri bulunmaktadır. Kurbanağa kaya resimleri ile Kaynak köyü kaya resimlerinde bulunan dağ keçisi ve hemen üzerinde bulunan güneş motifi bizlere aynı kozmik düşünceleri hatırlatmaktadır. Tek ressamın elinden çıkmış diyebileceğimiz Kurbanağa kaya resimlerindeki dağ keçisi figürleri ile Saymalıtaş'taki dağ keçisi figürlerinin bazıları yan profilden çizilmiş abartılı boynuzları ve hareketli tasvirleri ile dikkat çekmektedir (G. 18).
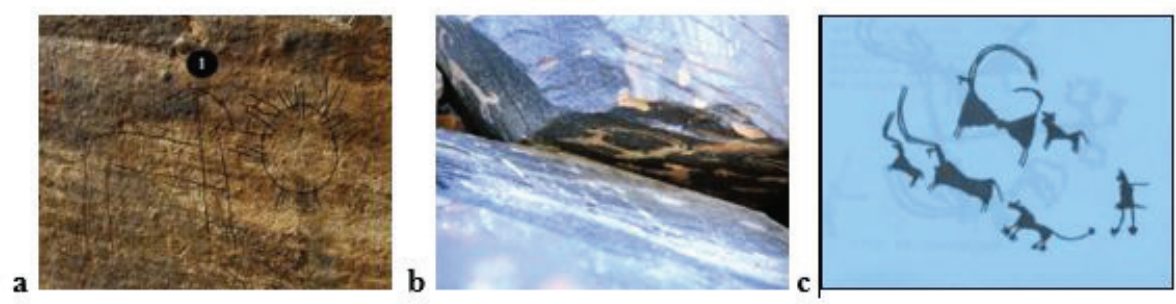

G. 18: a: Kaynak köyü, güneş sembolü ile karşı karşıya çizilmiş dağ keçisi figürü (A. Ceylan Arşivi). b: Saymalıtaş, sırt sırta vermiş boynuzları birbirine ulaşmış iki dağ keçisi figürü. (Somuncuoğlu, Saymalıtaş: Gökyüzü Atlarl, 88). c: Saymalıtaş, gövdeden basık abartılı boynuzlu dağ keçisi figürleri. (Tashbayeva, "Petroglyphs of Kyrgystan," fig: 20). 


\section{Cunni Mağarası ve Kaya Resimleri ${ }^{49}$}

Cunni Mağarası Erzurum ili, Karayazı ilçesi, Salyamaç köyünün 6 km kuzeydoğusunda, 2135 m rakımda bulunmaktadır (G. 27). Mağarada 50 adet damga ve 5 adet runik harf tespit edilmiştir. Toplamda 62'den fazla figür vardır. Bu figürler çizgi ve kabartma tekniği ile çizilmişlerdir. Bunların yanı sıra mağara içerisinde at, süvari ve dağ keçisi motifleri tespit edilmiştir. Mağaradaki damgalar ve runik harfler, çizgisel olarak ya da kabartma şeklinde çizilmiştir. Hayvan figürleri ise profilden çizgi tekniği ile resimlenmiştir ${ }^{50}$.

Mağaradaki bütün bu olumsuz şartlara rağmen, bir adet dağ keçisi figürü bütün hatları ile belirgin bir şekilde tespit edilebilmiştir. Dağ keçisi çizgi tekniği ile profilden, stilize bir şekilde çizilmiştir. Dağ keçisi figürünün gövdesi üzerine kısa bir boyun ve baş belirgin olarak ve boynuzlar geriye doğru kavisli ve ikili şekilde resmedilmiştir. Kuyruk gövdeden hafif çıkıntılı ve diktir. Dört bacak da belirlidir. Ayrıca bacaklardaki eklem belirtileri de çizimde verilmiştir fakat tırnak yoktur (G. 19).
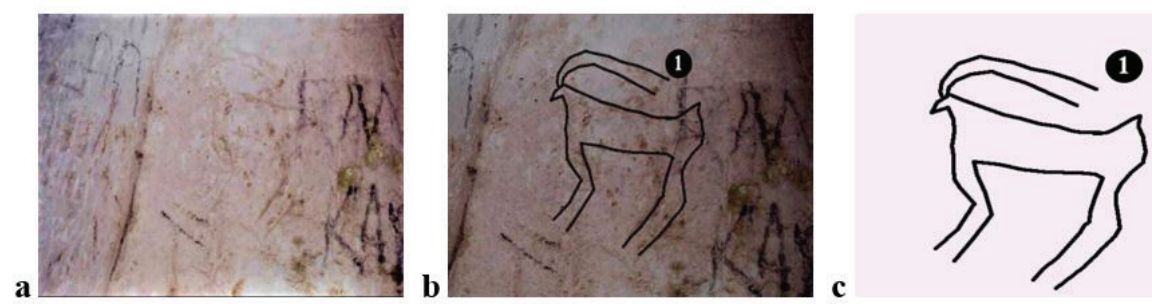

G. 19: a: Cunni Mağarası ve Kaya Resimleri Dağ Keçisi Motifi (A. Ceylan Arşivi). b, c: Cunni Mağarası ve Kaya Resimleri Dağ Keçisi Motifi Çizimi (A. Ceylan Arşivi).

Erzurum ili Karayazı ilçesi Cunni Mağarası ve kaya resimlerinin yakın coğrafyadaki Şenkaya/Kaynak köyü kaya resimleri, Dilli Vadisi kaya resimleri, Geyiklitepe kaya resimleri ve Kafkaslar'da Gobustan kaya resimleri ile mekân, stil, çizim tekniği, bağlam ve tema olarak benzerlikleri olduğu görülmektedir. Figürlerin işleniş tekniği ile runik harflerin ve damgaların varlığı ele alındığında ${ }^{51}$ resim alanının MS 1. binde çizildiği söylenebilir (G. 20).

$4939^{\circ} 36^{\mathrm{I}} 31^{\text {II }} \mathrm{N}-42^{\circ} 02^{\mathrm{I}} 40^{\text {II }} \mathrm{E}$. Cunni Mağarası'nın ilk keşfi 1965 yılında bölgede araştırmalar yürüten Dr. H. Vary ve Atatürk Üniversitesi Edebiyat Fakültesi Dekanı İ. Yalçın tarafından yapılmıştır. Daha sonra A. Ceylan tarafından incelenen mağarada bilimsel çalışmalar gerçekleştirilmiştir. Ardından tarafımızca tekrardan incelenmeler yapılmıştır.

50 Hermann Vary, "Alttürkische in Nordeast-Anatolien Ural-Altaische," Jahrbücher 40/1-2 (1968), 50-78; Ceylan, "Doğuda İlk Türk Yerleşmelerinden Cunni Mağarası," 425-429; Özgül, "Erzurum Bölgesi Kaya Panolar1," 174-176.

51 Viladimir A. Livşits, "Eski Türk Runik Yazısının Ortaya Çıkışı Üzerine,” 37-50. Doğan, Doğu Avrupa 'daki Göktürk (Runik) İşaretli Yazıtlar, 1-245; İbrahim Şahin, “İçel/Gülnar'da Eski Türklere Ait Yeni Tespit Edilmiş Epigrafik Belgeler: Tanıtımı ve Ön Değerlendirmesi," Türkiye Bilimler Akademisi Arkeoloji Dergisi XXXI (2012), 275-300; Doğan, Kafkaslardaki Göktürk (Runik) İsaretli Yazttlar, 1-244. 

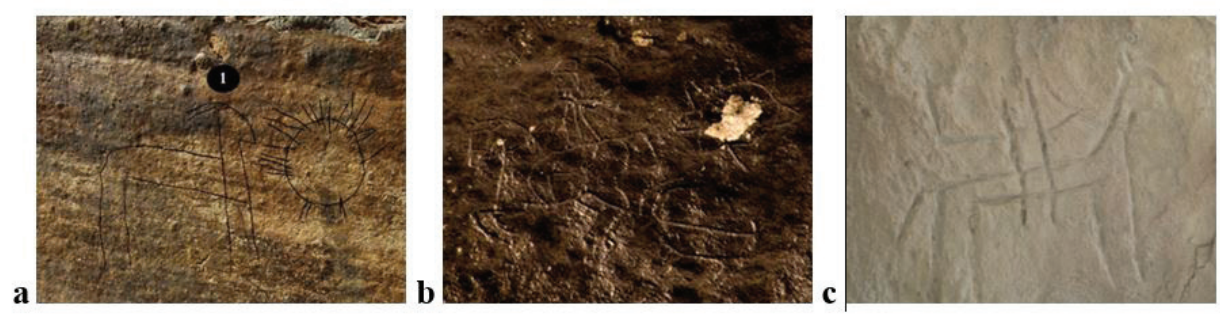

G. 20. a: Kaynak Köyü, çizgi teknigi ile profilden çizilmiş dağ keçisi (A. Ceylan Arşivi). b: Dilli

Vadisi, çizgi tekniği ile profilden çizilmiş stilize süvari (A Ceylan Arşivi). c: Gobustan, çizgi tekniği ile profilden çizilmiş süvari. (Galata, “Türklerde Kaya Resimleri ve Mezar Geleneği,” 200).

\section{Şenkaya Kaynak Köyü Kaya Resimleri ${ }^{52}$}

Şenkaya Kaynak Köyü kaya resimleri, Erzurum ili, Şenkaya ilçesi, Kaynak köyünün $7 \mathrm{~km}$ doğusunda $2329 \mathrm{~m}$ rakımda yer alır (G. 27). Andezit kayalık üzerine çizilen kaya resimlerinde 2 geyik, 2 yularlı at, 1 dağ keçisi ve güneş kursu profilden çizgi tekniği ile çizilmiştir. Ayrıca panoda kurt ya da köpek olarak tanımlayabileceğimiz iki çizim daha mevcuttur. Yine panoda hem alanın uğramış olduğu yoğun tahribat hem de tamamlanmamış çizimlerin olması sebebiyle tam olarak belirlenemeyen başka çizimler de mevcuttur ${ }^{53}$ (G. 21).

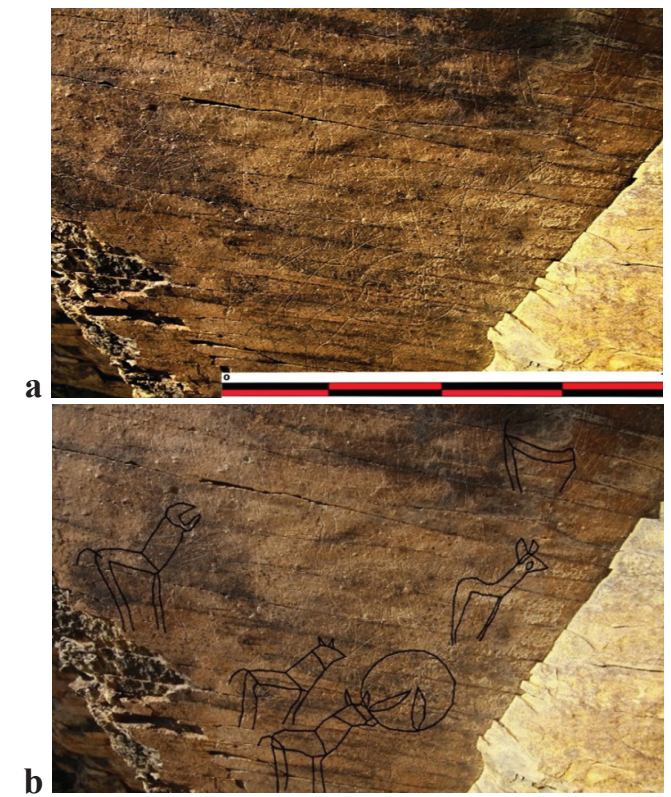

G. 21. a: Şenkaya Kaynak Köyü Kaya Resimleri Genel Görünümü (A. Ceylan Arşivi). b: Şenkaya Kaynak Köyü Kaya Resimleri Genel Çizimi (A. Ceylan Arşivi).

$5240^{\circ} 26^{\mathrm{I}} 36^{\mathrm{II}} \mathrm{N}-42^{0} 26^{\mathrm{I}} 49^{\mathrm{II}} \mathrm{E}$.

53 Cemal Sevindi ve Ali Yalçın Tavukçu, "Şirvaz Kalesi ve Kayaüstü Resimleri Şenkaya Erzurum,” Atatürk Üniversitesi Güzel Sanatlar Enstitüsü Dergisi 31 (2013), 155-173; Özgül, "Erzurum Bölgesi Kaya Panoları," 176-180; Özgül, “Erzurum Şenkaya Petrogliflerindeki At Geyik ve Güneş Kursu,” 172. 
Alanda bir adet dağ keçisi ana hatları ile tespit edilmiştir. Ancak alanın uğramış olduğu tahribat ve tamamlanmamış resimler içinde başka dağ keçisi figürlerinin olması muhtemeldir. Alanda tespit edilen dağ keçisi figürü, çizgi tekniği ile profilden çizilmiştir. Dağ keçisinin yüzü güneş kursuna dönüktür. Figür gövde çizgileri ile devam eden 4 bacağa sahiptir. Bacaklarda tırnak yoktur. Keçinin kafası belirli olup boynuzları arkaya doğru kavislidir. Keçi figürünün kuyruğu yoktur fakat alanın tahribatı neticesinde kuyruğun görünmediğini göz önünde bulundurmak gerekmektedir (G. 22).
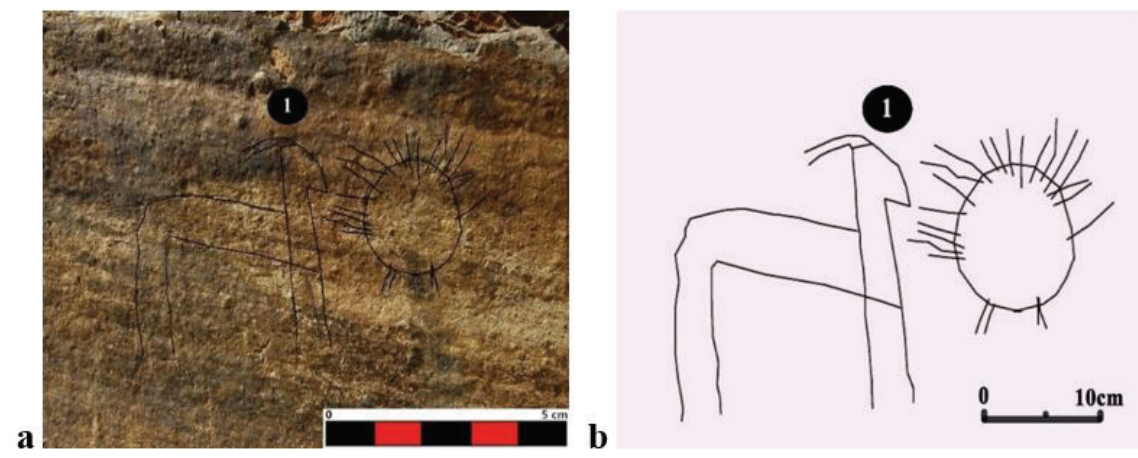

G. 22. a: Şenkaya Kaynak Köyü Kaya Resimleri Dağ Keçisi Motifi (A. Ceylan Arşivi). b: Şenkaya Kaynak Köyü Kaya Resimleri Dağ Keçisi Motifi Çizimi (A. Ceylan Arşivi).

Erzurum ili Şenkaya ilçesi Kaynak Köyü kaya resimlerinin Anadolu'da Kurbanağa kaya resimleriyle aynı kozmik düşüncenin ürünü olduğu görülmektedir. İki alanda da dağ keçisi ve güneş figürü dikkati çekmektedir. Kaya resim alanının kronoloji durumu net olmamakla birlikte resim alanının hemen üst tarafında bulunan Çağlayan kalesindeki keramik verileri Geç Tunç Çağ'a, Orta Demir Çă̆’a ve Orta Çă̆’a tarihlendirilmektedir ${ }^{54}$ (G. 23).

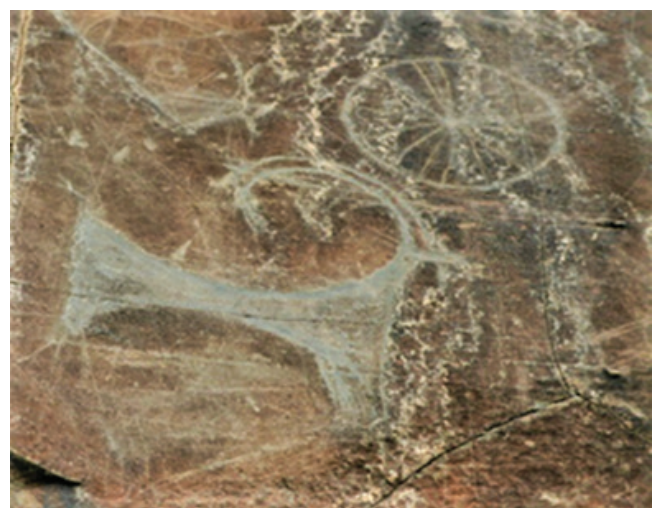

G. 23: Kurbanağa, dağ keçisi ile karşı karşıya çizilmiş güneş motifi (A. Ceylan Arşivi).

54 Ceylan, Doğu Anadolu Araştırmaları Erzurum-Erzincan-Kars-Iğdır 2008-2014, 291; Alpaslan Ceylan ve Yavuz Günaşdı, Erzurum 'un Eskiçağ Kaleleri (Erzurum: Atatürk Üniversitesi Yayınları, 2018), 156. 


\section{Dilli Vadisi Kaya Resim Alani ${ }^{55}$}

Erzincan ili Kemaliye ilçesinde bulunan resim alanı $1025 \mathrm{~m}$ rakımda bulunan kaya resim alanında toplam 11 figür mevcuttur (G. 27). Bunların 2'si dağ keçisi motifidir. Kaya resim alanındaki motifler tek bir panoda çizgi tekniği ile profilden çizilmiştir. Kayada bir süvari, iki dağ keçisi iki güneş kursu ve damga olabileceğini düşündüğümüz çizimler mevcuttur ${ }^{56}$ (G. 24).
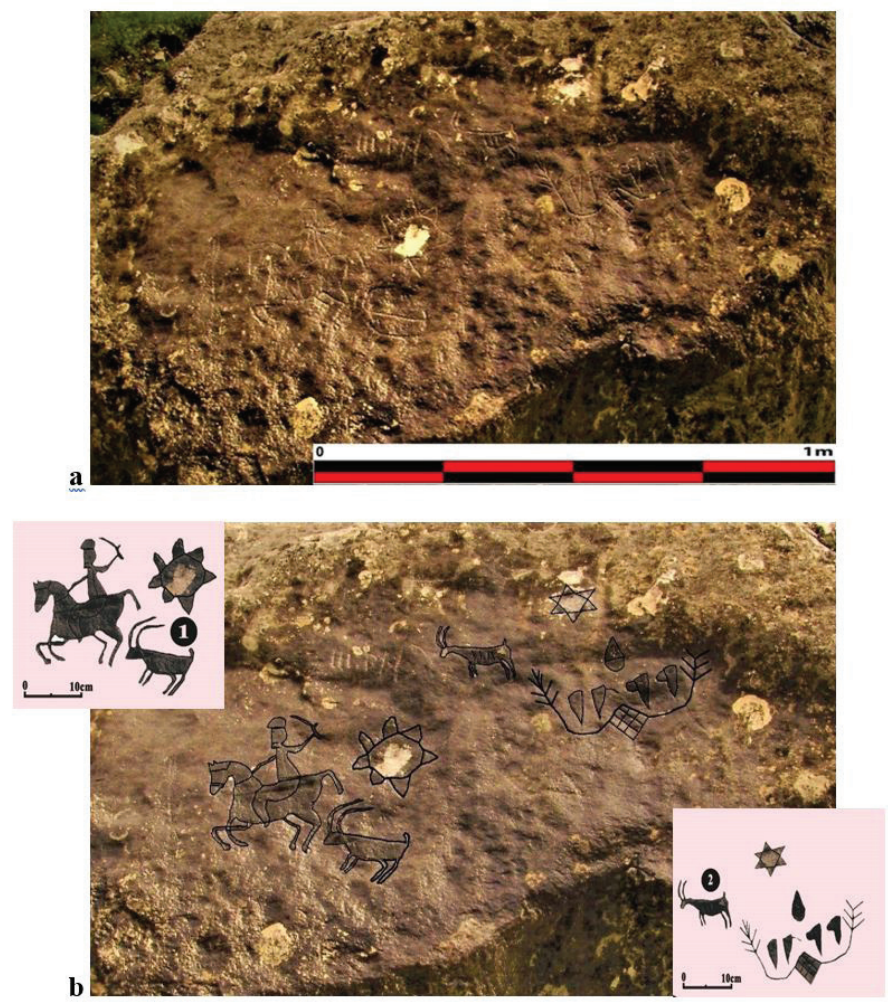

G. 24: a: Dilli Vadisi Kaya Resim Alanı Genel Görünümü (A. Ceylan Arşivi). b: Dilli Vadisi Kaya Resim Alanı Genel Çizimi (A. Ceylan Arşivi).

Alanda bulunan iki adet dağ keçisi figürü çizgi tekniği ile profilden çizilmişlerdir. Dağ keçilerinde gövde ayrıntılı olarak resmedilmiştir. Panonun üst kısmındaki 1 no.lu keçinin gövdesinde ovalliği verebilmek için tıpkı Geyiklitepe'de olduğu gibi omurgadan göbeğe inen hafif açılı çizgiler mevcuttur. Boyun uzantısı verilmiş olan çizimlerde kafa belirli olup boynuzlar ikili şekilde arkaya doğru kavislidir. Keçilerde dört bacakta belirtilmiş ve baldır ayrıntısı belli olmaktadır. Tırnak işlenmemiştir.

$5539^{0} 15^{\mathrm{I}} 50^{\mathrm{II}} \mathrm{N}-38^{0} 24^{\mathrm{I}} 03^{\text {II }} \mathrm{E}$

56 Ceylan, “Türk Dünyasından Yeni Kaya Resimleri,” 167-168; Üngör, “Türk Kültüründe Dağ Keçisi Teke,” 245-325. 
Süvarinin arkasındaki 2 no.lu dağ keçisi figürü hareketli vaziyette iken panonun üst kısmındaki figür hareketsiz çizilmiştir (G. 24).

Dilli Vadisi kaya resimlerini incelediğimizde bu resimlerin Anadolu'da Başköy, Doyumlu, Dereiçi, Tırşin ve Geyiklitepe kaya resimleri ile Kafkaslarda Gobustan kaya resimleri ile mekân, stil, çizim tekniği, bağlam ve tema olarak benzerlikler taşıdığı görülmektedir. Bu alanlardan Başköy, Doyumlu ve Dereiçi kaya resimlerindeki aynı profilden çizilmiş dört bacaklı süvari tasvirleri ortak figürler arasındadır. Dilli Vadisi dağ keçisi motifi ile Gevaruk ve Geyikli tepe kaya resimlerindeki dağ keçileri yan profilden çizilmiş dört bacaklı ve omurgadan göbeğe inen açılı çizgilerle gövde ovalliği verilmesi bakımından ortaktırlar. Gelişmiş bir işleme tarzı, figür detaylarının verilmesi ve damga olduğu düşünülebilecek işaretlere sahip olan Dilli Vadisi kaya resim alanının Erken Orta Çăg' da yapıldığ düşünülebilir (G. 25).
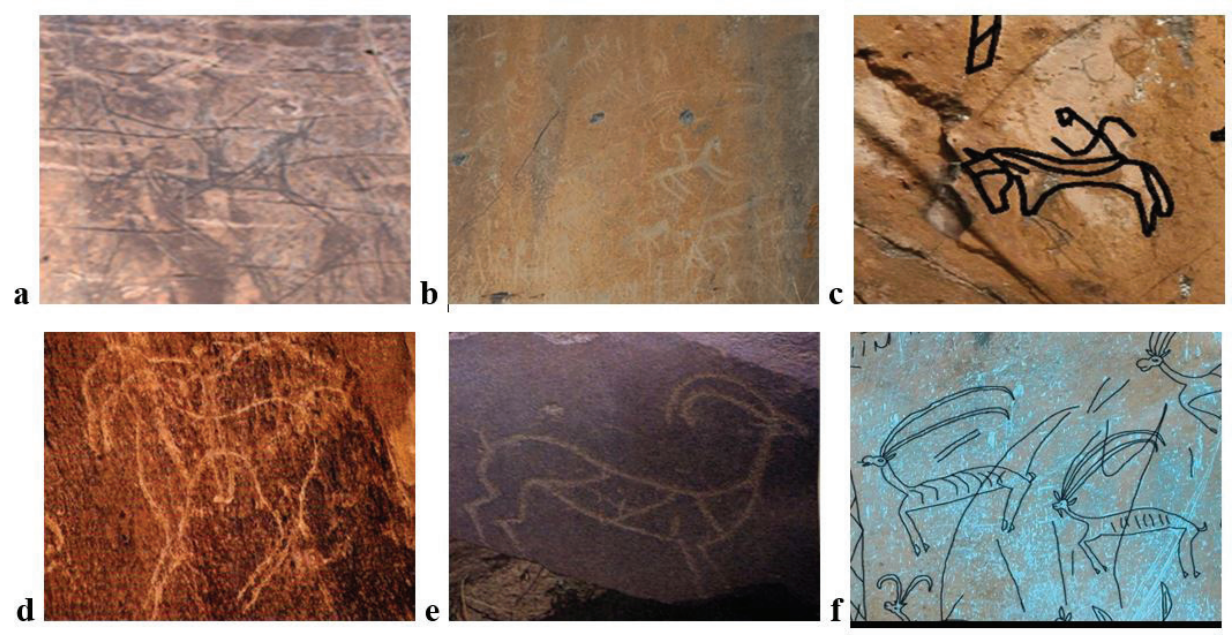

G. 25. a: Doyumlu, çizgi tekniği ile profilden çizilmiş elinde mızragı olan süvari ve av sahnesi (A. Ceylan Arşivi). b: Başköy, kazıma tekngiği ile profilden çizilmiş elinde mızragı olan süvari ve av sahnesi (A. Ceylan Arşivi). c: Dereiçi, Çizgi tekniği ile profilden çizilmiş süvari (A. Ceylan Arşivi). d: Gobustan, çizgi tekniği ile çizilmiş koşumlu at ve elinde kılıcı olan süvari. (Somuncuoğlu, Sibiryadan Anadolu'ya Taştaki Türkler, 445). e: Tırşin Yaylası, çizgi tekniği ile profilden çizilmiş dağ keçisi figürü. (Alok, Anadolu'da Kaya Üstü Resimleri, kapak fotoğrafi). f: Geyiklitepe, çizgi tekniği ile çizilmiş ve vücut ovalliği verilmiş dağ keçileri (A. Ceylan Arşivi). 
İncelemiş olduğumuz kaya resim alanlarının haricinde bölgede dağ keçisi motifinin bulunduğu; Çiçekli5 ${ }^{57}$, Dereiçi ${ }^{58}$, Karaboncuk-Çeşmebaş1 ${ }^{59}$, Karaboncuk ${ }^{60}$, Kömürlü ${ }^{61}$, Tunçkaya $^{62}$ ve Doyumlu ${ }^{63}$ kaya resimleri de bulunmaktadır ${ }^{64}$.

\section{Tarihlendirme}

Kaya resimlerindeki en büyük sorun tarihlendirme sorunudur. Bölgede çalışmaların henüz çok yeni olması ve bilimsel analizlerin eksik olmasından dolayı kaya resimlerinin tarihlendirilmesi konusu kesinlik kazanmamıştır. Anadolu'da kaya resimleri ile ilgili çalışmalar yürüten E. Anati, Karain, Öküzini, Tırşin, Gevaruk ve Çatak kaya resimlerini inceleyip gruplamalar yaparak tarihlendirme yoluna gitmiştir ${ }^{65}$. Bu örnekleri de göz önünde bulundurarak bu çalışma kapsamında Kuzeydoğu Anadolu petroglifleri üzerinde yapılan tarihlendirme çalışmalarının genelinde analojik ve arkeolojik yöntemler kullanıldı. Üzerinde çalışılan kaya resimlerini daha sağlıklı bir şekilde inceleyebilmek ve kökensel sorunlara az da olsa 1şık tutacak veriler elde edebilmek için ilk önce bu resimlerin Van-Hakkâri gibi yakın bölgelerdeki kaya resim alanları ile mukayesesi yapıldı. Daha sonra Kuzeybatı İran, Ermenistan ve Azerbaycan'daki kaya resimleri ile olan paralellikleri ve farklılıkları ele alındı.

Tüm bu görüş ve incelemeler sonucunda bölgedeki kaya resimlerinin Tunç Çağı'ndan itibaren ortaya çıktığı, Demir Çağ 1 ve Orta Çağ' da da yapılmaya devam ettiği sonucuna vardık. Erzurum-Van bölgesi kazılarında ortaya çıkan kaplardaki dağ keçisi motifinin de Tunç Çağı'ndan sonra ortaya çıktığı düşünülürse “dağ keçisi” nin bir sembol olarak Erken Tunç Çağı'ndan itibaren bölgede yaşayan insanlar tarafından figür olarak işlendiği düşünülebilir. Belirtiğimiz çömlekte abartılı boynuzlu, dik kuyruklu ve stilize boyanmış dağ keçisi figürleri bulunmaktadır. Yine hayat ağacı ve

57 Ceylan, "Türk Dünyasından Yeni Kaya Resimleri," 174-175; Alpaslan Ceylan, Akın Bingöl ve Mustafa Karageçi, Eski Çağda Kars Kaleleri (Erzurum: Atatürk Üniversitesi Yayınevi, 2018), 87.

58 Ceylan, "Doğu Anadolu'da İlk Türk İzleri," 219; Ceylan, "Türk Dünyasından Yeni Kaya Resimleri," 175176; Özgül, "Orta Asya Kaya Resimleri Işı̆ğında Kars-Ardahan Kaya Resimlerindeki Av ve Tuzak Sahneleri," 903; Ceylan, Bingöl ve Karageçi, Eski Çağda Kars Kaleleri, 87. İbrahim Üngör, "Orta Asya'dan Anadolu'ya Kayalara Yazılan Türk Kültürü (Dereiçi Kaya Resimleri)", Selçuk Üniversitesi Türkiyat Araşstırmaları Dergisi 39, 2016, 357-370.

59 Ceylan, "Türk Dünyasından Yeni Kaya Resimleri," 179; Ceylan, Bingöl ve Karageçi, Eski Çăgda Kars Kaleleri, 89.

60 Belli, "Kağızman Karaboncuk'da Tarih Öncesi Döneme Ait Kayaüstü Resimleri," 1- 10; Ceylan, "Türk Dünyasından Yeni Kaya Resimleri," 178; Ceylan, Bingöl ve Karageçi, Eski Çağda Kars Kaleleri, 89.

61 Ceylan, "Türk Dünyasından Yeni Kaya Resimleri," 179; Ceylan, Bingöl ve Karageçi, Eski Çağda Kars Kaleleri, 90.

62 Ceylan, "Türk Dünyasından Yeni Kaya Resimleri," 180-181; Ceylan, Bingöl ve Karageçi, Eski Çağda Kars Kaleleri, 90.

63 Yavuz Günaşdı, "Doğu Anadolu Kaya Resimleri Işı̆̆ında Doyumlu Kaya Panoları," Selçuk Üniversitesi Türkiyat Araşttrmaları Dergisi 1/39 (2016), 391-407; Ceylan, "Türk Dünyasından Yeni Kaya Resimleri," 170; Ceylan, Bingöl ve Karageçi, Eski Çağda Kars Kaleleri, 92.

64 Bingöl, "Kuzeydoğu Anadolu Petrogliflerindeki Dağ Keçisi Motifi,” 70-175.

65 Anati, “Anatolia’s Earliest Art," 22-35; Anati, Arte Prehistorica in Anatolia, 1-50. 
su kuşları da dikkati çeken diğer motiflerdir (G. 26). Çömlekteki dağ keçisi motifi ile Başköy, Digor ve Kurbanağa kaya resimlerinde figürler arasında benzerlikler bulunmaktadır. Çömlekte bulunan hayat ağacı motifiyle Geyiklitepe ve Emir Kazgan kaya resimlerinde bulunan hayat ağacı motifleri de benzerdir. Bununla birlikte bölgedeki kaya resimlerini biçim ve tema yönünden "Göçer Hayvan Üslubunun”"66 bir parças1 olarak değerlendirmek mümkündür. Bu üslubun MÖ I. binden itibaren Anadolu’ya İskitler yolu ile taşındığını da hesaba katarsak daha sağlıklı sonuçlara ulaşabiliriz. Yeni tarihlendirme ve analiz yöntemleri bulunana kadar yapmış olduğumuz tasnif çalışmaları alandaki çalışmalara katkı sağlanmış olacaktır.

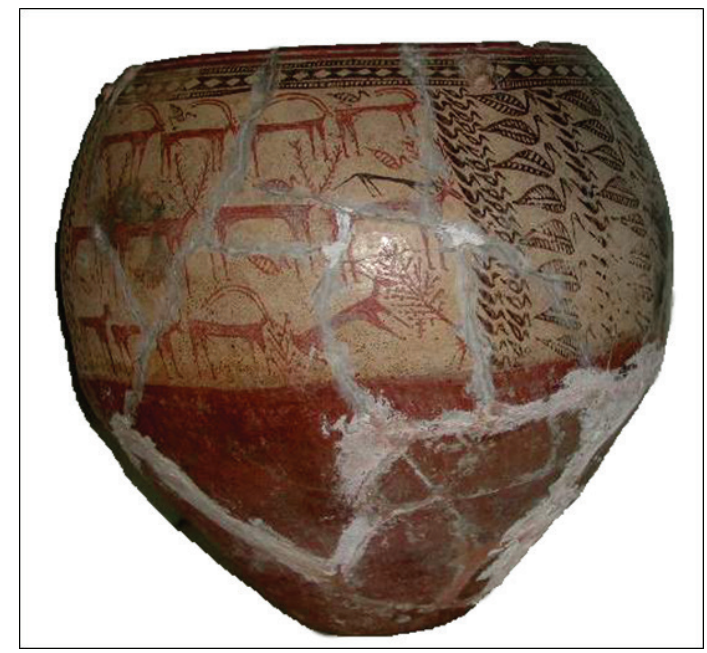

G. 26: Dağ Keçisi Bezemeli Tunç Dönemi Çömlek (Erzurum Arkeoloji Müzesi)

\section{Sonuç}

Çalışma alanımız olan Kuzeydoğu Anadolu Bölgesi (Kars-Ardahan-ErzurumErzincan)'nde, içinde dağ keçisi figürü barındıran 16 kaya resim alanı mevcuttur. Bu makale kapsamında örnek ve ayırt edici olması sebebiyle Kars'tan 5, Erzurum'dan 2, Ardahan ve Erzincan'dan 1'er merkezde çalışma yapılımıştır. Bu resim alanlarında insan, dağ keçisi, geyik, at, yaban koyunu, sığır, süvari, güneş kursu, tuzak, tilki, köpek,

66 Sergei Ivanovich Rudenko, Dağglk Altay Buluntuları ve İskitler, çev. Almagül İsina, (Moskova: SSCB İlimler Akademisi Yayınlar1, 1952), 127; Eustace Dockray Phillips, The Royal Hordes: Nomad Peoples of the Steppes (London: Thames \& Hudson, 1965), 55-64; Nejat Diyarbekirli, Hun Sanatı (İstanbul: Milli Eğitim Basımevi 1972), 114-131; Emel Esin, Íslamiyet ten Önceki Türk Kültür Tarihi ve İslam 'a Giriş (İstanbul: Edebiyat Fakültesi Yayınevi, 1978), 107-116; Anıl Yılmaz, "İskit Sanatı,” Türkler Ansiklopedisi, c. 4 (Ankara: Yeni Türkiye Yayınları, 2002), 26-32; Mehmet Taner Tarhan, “Ön Asya Dünyasında İlk Türkler Kimmerler ve İskitler,” Türkler Ansiklopedisi, c. 1, (Ankara: Yeni Türkiye Yayınları, 2002), 601-602; İhami Durmuş, "İskit Kültürü,” Türkler Ansiklopedisi, c. 4, (Ankara: Yeni Türkiye Yayınları, 2002), 21-22; Yaşar Çoruhlu, "Hun Sanat1," Türkler Ansiklopedisi, c. 4, (Ankara: Yeni Türkiye Yayınları, 2002), 54-76; Andrzej Rozwadowski, Symbols Through Time Interpreting the Rock Art of Central Asia, çev. A. Pietrzak (Poznan: Institute of Eastern Studies, 2004), 87-96; Yaşar Çoruhlu, Türk Sanatında Hayvan Sembolizmi I (İstanbul: Ötüken Yayınevi, 2019), 234-261. 
domuz figürleri, damgalar ve runik yazılar ile karşılaşılmaktadır. İncelenen kaya resim alanları, figür sayısı bakımından oldukça zengindir. Toplamda 9 merkezde 368 'in üzerinde figür tespit edilmiştir. Bu figürlerin 119'undan fazlası ise dağ keçisi motifidir.

Bu resim alanları ortalama 1955 m rakımdadır. Bu yükselti, Van-Hakkâri-Kafkaslar ve Orta Asya kaya resimleri ile kıyaslandığında mekân özellikleri ve yüksek bölgelerin özenle seçilmesi konusunda paralellik arz etmektedir. Bu yükseltiler, yerleşik halkın yaşayabileceği coğrafyalar olmadığından burada göçerlerin yaşadığı düşünülmektedir. Dolayısıyla kaya resimlerinin büyük bir kısmının göçer insanlara ait olduğu söylenebilir. Kaya resimlerinin yakınlarında bu kültürlerle ilişkili olabilecek bağımsız mezar yapılarının bulunması, bunun en büyük kanıtı olarak kabul edilebilir. Yapılacak kazı çalışmaları bu görüşümüzü daha da kuvvetlendirecektir.

Çalışma alanında tespit edilen 119 kadar dağ keçisi incelendiğinde bazı ayırt edici özellikler dikkat çekmektedir. Çizilmiş olan dağ keçileri genelde baş, gövde ve ayak şeklinde üç ana hattan oluşmuştur. Çizilen baş kısımları bazen belirgin bazen de belirsiz olarak karşımıza çıkmaktadır. Baş üzerinde muhakkak boynuz vardır. Boynuzlar ya geriye doğru kavisli abartılı ya da normal boynuz şeklindedir. Profil açısına göre her iki boynuz türünde de boynuzlar bazen tek bazen çift olarak çizilmişlerdir. Çizilen gövdeler incelediğinde, gövdenin bazen şematik, bazen çizgisel bazen de normal şekilde çizildiği görülmektedir. Gövdede bulunan abartısız boynuzlar, bunların dişi ya da oğlak olması ihtimalini güçlendirmektedir. Yine gövdede bulunan erekte fallus, kavisli abartılı boynuz ve dik kuyruk belirtilerine sahip olan figürlerin teke olması muhtemeldir. Ayaklar hareketli ve hareketsiz olarak karşımıza çıkmaktadır. Hareketli bacaklarda eklem ve tırnaklar genellikle belirgindir. Hareketsiz olanlar ise düz tarzda çizilmiştir. Profil açısına göre her iki bacak türünde de bacaklar çift ya da tek olarak resmedilmiştir (G. 27, G. 28). 


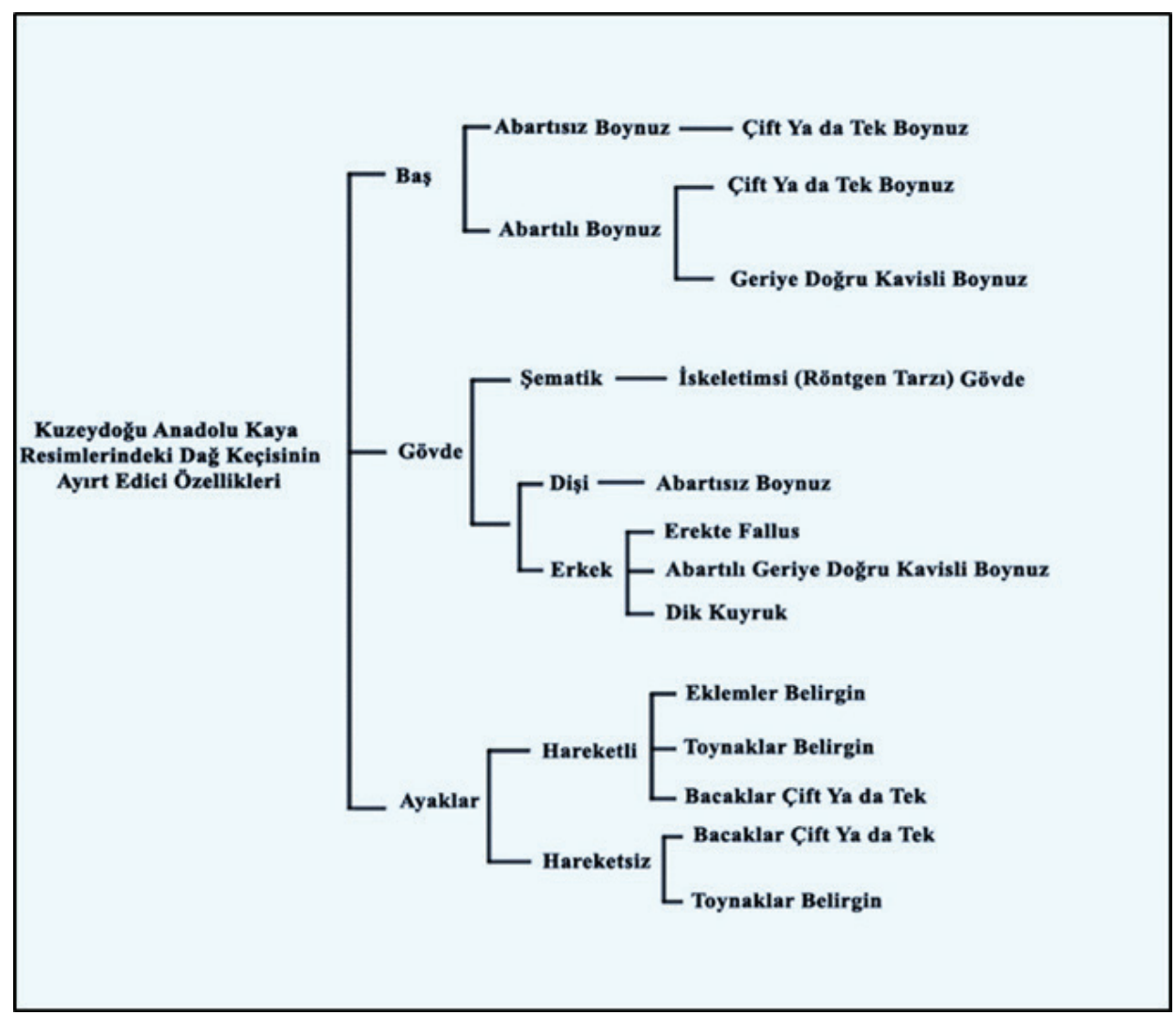

G. 27: Kuzeydoğu Anadolu Kaya Resimlerindeki Dağ Keçisi Motifinin Ayırt Edici Özellikleri (Bingöl, "Kuzeydoğu Anadolu Petrogliflerindeki Dağ Keçisi Motifi,” 215.) 


\begin{tabular}{|c|c|c|c|c|c|c|c|c|c|c|c|}
\hline & \multicolumn{9}{|c|}{ MERKEZLER } & \multirow[b]{2}{*}{ 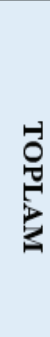 } \\
\hline & & 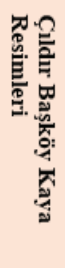 & 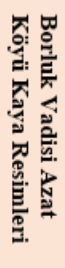 & 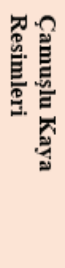 & 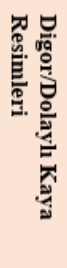 & 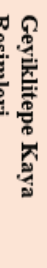 & 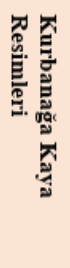 & 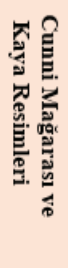 & 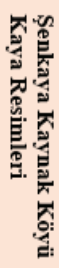 & 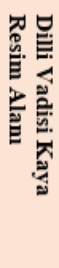 & \\
\hline \multirow{13}{*}{ 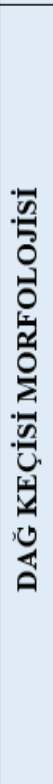 } & Erkek & 4 & 9 & 4 & 8 & 6 & $40 ?$ & 1 & - & 2 & 74 \\
\hline & Diși & 1 & 3 & - & - & - & - & - & - & - & 4 \\
\hline & Dik Kuyruk & - & - & 7 & 3 & 4 & 22 & 1 & - & 2 & 39 \\
\hline & Erekte Fallus & - & 4 & 1 & - & - & - & - & - & - & 5 \\
\hline & Hareketli & 5 & 2 & - & - & - & 5 & - & & 1 & 13 \\
\hline & Hareketsiz & - & 10 & 9 & 10 & - & 40 & - & 1 & 1 & 71 \\
\hline & Eklemler Belli & - & - & - & - & 8 & - & 1 & - & 1 & 10 \\
\hline & Şematik Gövdeli & - & 1 & - & - & 5 & - & - & - & 1 & 7 \\
\hline & Çift Bacak & - & 3 & - & - & - & 28 & - & - & - & 31 \\
\hline & Dört Bacak & 5 & 9 & 9 & 10 & 9 & 3 & 1 & 1 & 2 & 49 \\
\hline & Abartılı Boynuz & 5 & 8 & 3 & 9 & - & 37 & 1 & 1 & 2 & 66 \\
\hline & Tek Boynuz & - & 2 & 3 & - & - & 5 & - & - & - & 10 \\
\hline & Çift Boynuz & 5 & 10 & 6 & 9 & 13 & 32 & 1 & - & 2 & 78 \\
\hline
\end{tabular}

G. 28: Kuzeydoğu Anadolu Bölgesi Kaya Resimleri Dağ Keçisi Morfolojisi (O. Özgül-B. Bingöl, 2021)

Sonuç olarak Kuzeydoğu Anadolu yaylalarında çoğunlukla Erken Tunç Çağı'ndan itibaren ortaya çıkan ve dönemsel farklılık gösteren kaya resimleri, yakın çevrede VanHakkâri dağlık bölgesi kaya resimleri ile benzer bir kültür birlikteliği içindedir. İkincil kültür çevresinde Kuzeybatı İran, Ermenistan, Azerbaycan, Nahçıvan ile benzeşen Kuzeydoğu Anadolu kaya resimleri, kök bakımından Avrasya kıtası kaya resim sanatına bağlanmaktadır. Bu benzerliğe Hakkâri Stelleri'ni, Doğu Anadolu'da çıkan Orta Asya tarzındaki diğer heykel ve damgalar ile bazı kurgan tipindeki mezar yapıları gibi göçer kültür öğeleri de eklenirse, bölgenin göçer kültürlerle ilişsisi belki daha iyi anlaşılabilir. MÖ II. binden itibaren yaklaşı 10 milyon $\mathrm{km}^{2}$ 'lik bir coğrafyaya yayılan bozkır kültürünün ve sanatının bu bölgeyi atlaması düşünülemezdi. Kronoloji ve kısmi köken sorunlarına rağmen, kaya resimlerindeki hayvan üslubunun bazı değişmelerle yoluna devam etmesi ve kendini yenilemesi, bozkır sanatının en bariz özelliklerindendir. Bu yönü ile Kuzeydoğu Anadolu kaya resimleri, bu sanatın özünü koruyarak değişime uğramış formlarını yansıtmaktadır. 
Hakem Değerlendirmesi: Dış bağımsız.

Çıkar Çatışması: Yazarlar çıkar çatışması bildirmemiştir.

Finansal Destek: Yazarlar bu çalışma için finansal destek almadığını beyan etmiştir.

Peer-review: Externally peer-reviewed.

Conflict of Interest: The authors has no conflict of interest to declare.

Grant Support: The authors declared that this study has received no financial support.

\section{Kaynakça/References}

Alimov, Risbek. "Kırgızistan'da Yeni Bulunan Runik Harfli Eski Türk Yazıtları Hakkında Ön Bilgiler.” Türk Dili Araştırmaları Yillı̆̆ı-Belleten 48 (2000): 5-10.

Alok, Ersin. Anadolu'da Kaya Üstü Resimleri. İstanbul: Akbank Yayınları, 1988.

Amanbaeva, Bakyt, Aiday Suleymanova ve Chynarbek Zholdoshov. "Rock Art Sites in Kyrgyzstan." Rock Art in Central Asia. Ed. Jean Clottes. Paris: International Council on Monuments and Sites, 2011, 43-73.

Amanjolov, Altay. “Ataların Sözleri.” Erdem 5/15 (1989): 797-802.

Anati, Emanuel. “Anatolia’s Earliest Art”. Archaeology 21/1 (1968): 22-35.

Anati, Emanuel. Arte Prehistorica in Anatolia. Studi Camuni vol. 4 Italia: Capo di Ponte Edizioni del Centro, 1972.

Belli, Oktay. “Kağızman Karaboncuk'da Tarih Öncesi Döneme Ait Kayaüstü Resimleri.” Arkeoloji ve Sanat Dergisi 121 (2006): 1- 10.

Belli, Oktay. "Kars - Borluk Vadisi Kayaüstü Resimleri.” Arkeoloji ve Sanat Dergisi 122 (2006): 11-22.

Belli, Oktay. "Van Bölgesi'ndeki Yeni Boyalı Mağara Resimleri.” Homo Amatus: Güven Arsebük için Armağan Yazıları. Ed. Mihriban Özbaşaran, Oğuz Tanındı ve Ahmet Boratav, İstanbul: Ege Yayınları, 2003, 29-42.

Binandeh, Ali. "Looking at Rock Art in Northwest of Iran." International Journal of Archaeology. Special Issue: Rock Art, Handmade Architecture, Historical Archaeology 4/1-1 (2016): 12-17.

Bingöl, Akın. "Yüzey Araştırmaları Işı̆̆ında Borluk Vadisi Kayaüstü Resimleri.” Selçuk Üniversitesi Türkiyat Araştırmaları Dergisi 39 (2016): 347-355.

Bingöl, Burak. "Kuzeydoğu Anadolu Petroğliflerindeki Dağ Keçisi Motifi.” Yüksek Lisans Tezi, Atatürk Üniversitesi, 2020.

Ceylan, Nezahat ve Yavuz Günaşdı. "Doğu Anadolu'da Bulunan Bazı Taş Heykellerin Orta Asya'daki Örnekler İle Mukayesesi.” 16. Uluslararası Türk Dünyası Sosyal Bilimler Kongresi (4-6 Eylül 2018 Çimkent), İstanbul: Türk Dünyası Araştırmaları Vakfı Yayınları, 2018, 633-646.

Ceylan, Alpaslan ve Nezahat Ceylan. Doğunun Sönmeyen Yıldızı Akçakale. Erzurum: Atatürk Üniversitesi Yayınevi, 2018.

Ceylan, Alpaslan, Akın Bingöl ve Mustafa Karageçi. Eski Çağda Kars Kaleleri. Erzurum: Atatürk Üniversitesi Yayınevi, 2018.

Ceylan, Alpaslan ve Yavuz Günaşdı. Erzurum 'un Eskiçă̆ Kaleleri, Erzurum: Atatürk Üniversitesi Yayınlar1, 2018.

Ceylan, Alpaslan. "Doğuda İlk Türk Yerleşmelerinden Cunni Mağarası.” Türkler Ansiklopedisi. 4. cilt. Ankara: Yeni Türkiye Yayınları, 2002, 425-429. 
Ceylan, Alpaslan. “Doğu Anadoluda İlk Türk İzleri.” XV. Türk Tarih Kongresi I (11-15 Eylül 2006), Ankara: Türk Tarih Kurumu Yayınları, 2006, 215-232.

Ceylan, Alpaslan. Doğu Anadolu Araştırmaları Erzurum-Erzincan-Kars-Ĭ̆glı 1998-2008. Erzurum: Güneş Vakfi Yayınevi, 2008.

Ceylan, Alpaslan. "Çıldır Başköy Kaya Resimleri." Ardahan Üniversitesi İnsani Bilimler ve Edebiyat Fakültesi Dergisi BELGÜ 2/2 (2015): 9-24.

Ceylan, Alpaslan. Doğu Anadolu Araştırmaları Erzurum-Erzincan-Kars-Iğdır 2008-2014. Erzurum: Atatürk Üniversitesi Yayınevi, 2015.

Ceylan, Alpaslan. "Geyiklitepe Kaya Resimleri ve Runik Yazıtları.” III. Uluslararası Türk Şöleni Türk Kültürü Sempozyumu Bildirileri (17-19 Mayıs 2012 Erzurum), Erzurum: Güneş Vakfı Yayınları, 2016, 85-96.

Ceylan, Alpaslan. “Türk Dünyasından Yeni Kaya Resimleri.” XVII. Türk Tarih Kongresi I (15-17 Eylül 2014), Ankara: Türk Tarih Kurumu Yayınları 2018, 155-206.

Ceylan, Alpaslan. “Doğu Anadolu'da Erken Dönem Türk İzleri III Kars-Digor (Dolaylı) Kaya Resimleri.” TTK Kongresi’nde sunulan bildiri, Ankara, 1-5 Ekim 2018.

Ceylan, Nezahat. “Kağızman'da Tarihi ve Arkeolojik Araştırmalar.” Yüksek Lisans tezi, Kafkas Üniversitesi, 2007.

Ceylan, Nezahat. “Türk Kültüründe Geyik Kavramı ve Kuzeydoğu Anadolu Kaya Resimlerindeki Geyik Tasvirleri.” IV. Uluslararası Türk Şöleni Türk Kültürü Sempozyumu Bildirileri (17-19 Mayıs 2016 Erzurum), Erzurum: Güneş Vakfı Yayınları, 2018, 871-891.

Çoruhlu, Yaşar. "Hun Sanatı.” Türkler Ansiklopedisi. c. 4. Ankara: Yeni Türkiye Yayınları, 2002, 54-76.

Çoruhlu, Yaşar. Türk Sanatında Hayvan Sembolizmi I. İstanbul: Ötüken Yayınevi, 2019.

Diyarbekirli, Nejat. Hun Sanatı. İstanbul: Milli Eğitim Basımevi, 1972.

Doğan, İsmail. Doğu Avrupa'daki Göktürk (Runik) İşaretli Yazıtlar. Ankara: Türk Dil Kurumu Yayınlar1, 2002.

Doğan, İsmail. Kafkaslardaki Göktürk (Runik) İşaretli Yazıtlar. Ankara: Türk Dil Kurumu Yayınları, 2019.

Durmuş, İlhami. “Anadolu’da Kimmerler ve İskitler.” Belleten LXI (1997): 273-286.

Durmuş, İhami. “İskit Kültürü.” Türkler Ansiklopedisi. c. 4. Ankara: Yeni Türkiye Yayınları, 2002, $15-25$.

Durmuş, İlhami. “Orta Asya'dan Anadolu'ya Türk Konar- Göçer Kültürü.” Orta Asya Türk Kültürünün Anadolu Kültürüne Etkileri Uluslararası Sempozyumu (19 Haziran 2019 Taşkent), Ankara: Hacı Bayram Veli Üniversitesi Yayınları, 2019, 11-35.

Esin, Emel. İslamiyet'ten Önceki Türk Kültür Tarihi ve İslam'a Giriş. İstanbul: Edebiyat Fakültesi Yayınevi, 1978.

Farajova, Malahat. "Gobustan Rock Art Cultural Landscape - El paisaje cultural del arte rupestre de Gobustán.” Cuadernos De Arte Rupestre 7/2 (2014): 13-232.

Galata, Yasin Cemal. "Türklerde Kaya Resimleri ve Mezar Geleneği.” Doktora tezi, Mimar Sinan Güzel Sanatlar Üniversitesi, 2020.

Günaşd1, Yavuz. “Doğu Anadolu Kaya Resimleri Işı̆̆ında Doyumlu Kaya Panoları.” Selçuk Üniversitesi Türkiyat Araştırmaları Dergisi 1/39 (2016): 391-407. 
Günaşdı, Yavuz. “Karasu (Yukarı) Havzasındaki Tarihi ve Arkeolojik Veriler.” Doktora tezi, Atatürk Üniversitesi, 2013.

Harmankaya, Savaş ve Oğuz Tanındı. Türkiye Arkeolojik Yerleşmeleri. İstanbul: Ege Yayınları, 1996. Herodotos. Herodotos Tarihi. Çev. Müntekim Ökmen, İstanbul: Remzi Kitabevi, 1991.

Hoppal, Mihally. Şamanlar ve Semboller; Kaya Resmi ve Göstergebilim. Çev. Fatih Sel. İstanbul: Yapı Kredi Yayınları, 2015.

Karpuz, Haşim. "Çamuşlu'da Yontma Taş Çağı Kaya Resimleri.” Tübitak Bilim ve Teknik 10/212 (1977): 1-6.

Kazemi, Mohammad, Hossein Naseri Someeh, Esmail Hemati Azandaryani ve Mohammad Mirzaei. “An Introduction of ShikhMedi Newly Found Petroglyphs in Meshginshahr, Northwest Iran”. International Journal of Archaeologyi Special Issue: Rock Art, Handmade Architecture, Historical Archaeology. 4/1-1 (2016): 18-22.

Kozbe, Gülriz ve Alpaslan Ceylan vd. Türkiye Arkeolojik Yerleşmeleri-4 (TAY) Demir Çağları 1/2. İstanbul: Ege Yayınları, 2008.

Kökten, İsmail Kılıç. "Kars Çevresinde Dip Tarih Araştırmaları ve Yazılıkaya Resimleri.” Atatürk Konferanslarl (1975): 95-104.

Kökten, İsmail Kılıç. "Yazılıkaya'da ve Kurbanağa Mağarasında (Kars-Çamuşlu) Yeni Bulunan Dip Tarih Resimleri.” Karseli 6/69 (1970): 2-16.

Ksenophon. Anabasis (Onbinlerin Dönüşü). Çev. Tanju Gökcöl. İstanbul: Hürriyet Yayınları, 1998.

Livşıts, Viladimir A. "Eski Türk Runik Yazısının Ortaya Çıkışı Üzerine.” Çev. Saadettin Gömeç ve Tamara Ölçekçi, Ankara Üniversitesi Dil ve Tarih-Coğrafya Fakültesi Dergisi 20/31 (2000): 37-50.

Martinov. A. İ. Altay Kaya Resimleri Biçiktu-Boom. Çev. Zeynep Bağlan Özer. Ankara: Atatürk Kültür, Dil ve Tarih Yüksek Kurumu Atatürk Kültür Merkezi, 2013.

Mert, Osman. “Kemaliye'de Eski Türk İzleri: Dilli Vadisindeki Petroglif ve Damgalar.” Atatürk Üniversitesi Türkiyat Araştırmaları Enstitüsü Dergisi 34 (2007): 233-254.

Muvaffak, Uyanık. Petroglyphs of South - Eastern Anatolia. Graz: Akademische Druck und Verlagsanstalt, 1974.

Özgül, Oktay ve Nezahat Ceylan. "Göçerlik Ve Yerleşiklik Arasında Bir Bileşen; Fergana Vadisi." Prof. Dr. Fuat Sezgin Anisına Geçmişten Günümüze Türkistan: Tarih, Kültür Ve Medeniyet Seтроzуити (11-12 Nisan 2019 Türkistan), Ankara: Ahmet Yesevi Üniversitesi Yayınları, 2019, 472- 495.

Özgül, Oktay. "Erzurum Bölgesi Kaya Panoları.” Trakya Üniversitesi Edebiyat Fakültesi Dergisi 5/10 (2015): 169-198.

Özgül, Oktay. "Çoruh ve Kür Vadisinde Kimmer-İskit Yer Adları.” Ardahan Üniversitesi İnsani Bilimler ve Edebiyat Fakültesi Dergisi BELGÜ 2 (2015): 159-179.

Özgül, Oktay. "Erzurum Şenkaya Petrogliflerindeki At Geyik ve Güneş Kursu.” Selçuk Üniveresitesi Türkiyat Araştırmaları Enstitüsü Dergisi 39 (2016): 371-396.

Özgül, Oktay. “Eskiçağda Yukarı Aras Vadisi.” Doktora tezi, Atatürk Üniversitesi, 2011.

Özgül, Oktay. "Orta Asya Kaya Resimleri Işığında Kars-Ardahan Kaya Resimlerindeki Av ve Tuzak Sahneleri.” IV. Türk Şöleni Bildirileri, Erzurum: Güneş Vakfı Yayınları, 2018, 893-911.

Özgül, Oktay. "Erzurum Ve Çevresinde Erken Dönem Türk İzlerine Ait Yeni Bulgular.” Atatürk Üniversitesi Edebiyat Fakültesi Dergisi 65 (2020): 219-245 
Phillips, Eustace Dockray. The Royal Hordes: Nomad Peoples of the Steppes. London: Thames \& Hudson, 1965.

Rozwadowski, Andrzej. Symbols through Time Interpreting the Rock Art of Central Asia. Çev. A. Pietrzak. Poznan: Institute of Eastern Studies, 2004.

Rudenko, Sergei Ivanovich. Dağlık Altay Buluntuları ve İskitler. Çev. Almagül İsina Moskova: SSCB İlimler Akademisi Yayınları, 1952.

Saltoğlu, Cengiz. Unutulmuş Bir Geçmişten Oğuz-Kıpçak Sesler - Esatlı Yazıtları I-II. Antalya: Kutlu \& Avc1 Ofset, 2018.

San, Oya. “Bazı Bulgular Ișığında Anadolu'da Kimmer ve İskit Varlığı Üzerine Gözlemler.” Belleten C: LXIV/1 (1998): 1-21.

Sevin, Veli ve Aynur Özfirat. "Hakkari Stelleri: ve Doğu Anadolu'da İlk Çobanlar.” Belleten LXV/243 (2001): 501- 518.

Sevin, Veli. Hakkari Taşları Çıplak Savaş̧̧ıların Gizemi. İstanbul: Yapı Kredi Yayınları, 2005.

Sevin, Veli. Hakkari Taşları II Gizemin Peşinde. Ankara: Türk Tarih Kurumu Yayınevi, 2015.

Sevindi, Cemal ve Ali Yalçın Tavukçu. "Şirvaz Kalesi ve Kayaüstü Resimleri Şenkaya Erzurum." Atatürk Üniversitesi Güzel Sanatlar Enstitüsü Dergisi 31 (2013): 155-173.

Seyidov, Abbas. “Azerbaycan Halkının Taş Hafızası-Gobustan-Gemikaya Petroglifleri.” V. Uluslararası Halk Kültürü ve Sanat Etkinlikleri Sempozyumu (12-14 Ekim 2017 Ankara), Ankara: Gazi Üniversitesi Yayınları, 2017, 409-418.

Sieveking, Ann. Cave Artist. London: Thames \& Hudson, 1979.

Somuncuoğlu, Servet. Damgaların Göçü Kurgan. İstanbul: İletişimce Fotoğraf ve Danışmanlık Hizmetleri, 2012.

Somuncuoğlu, Servet. Saymalıtaş: Gökyüzü Atları. İstanbul: Atok Yayınları, 2011.

Somuncuoğlu, Servet. Sibiryadan Anadolu'ya Taştaki Türkler. İstanbul: Atok Yayınları, 2011.

Soydan, Ersoy ve Ferhat Korkmaz. "Batman'da Yeni Bir Keşif: Deraser (Arık) Mağara Resimleri." Turkish Studies - International Periodical For The Languages, Literature and History of Turkish or Turkic 8/6 (2013): 665-686.

Şahin, İbrahim. “İçel/Gülnar'da Eski Türklere Ait Yeni Tespit Edilmiş Epigrafik Belgeler: Tanıtımı ve Ön Değerlendirmesi.” Türkiye Bilimler Akademisi Arkeoloji Dergisi XXXI (2012): 275-300.

Tarhan, Mehmet Taner. “Ön Asya Dünyasında İlk Türkler Kimmerler ve İskitler.” Türkler Ansiklopedisi. c. 1. Ankara: Yeni Türkiye Yayınları, 2002, 597-610.

Tashbayeva, Kadıça. "Petroglyphs of Kyrgystan." Petroglyphs of Central Asia. Ed. Kadıça Tashbayeva. Bishkek: International Institute for Central Asian Studies, 2001, 9-80.

Tokhatyan, Karen. “Rock Carvings Of Armenia.” Fundamental Armenology 2 (2015): 184-204.

Tümer, Hale. "Van-Hakkari Dağlık Bölgesi Kaya Resimleri." Yüksek Lisans tezi, İstanbul Üniversitesi, 2017.

Türkçe Sözlük. Ankara: Türk Dil Kurumu Yayınları, 2010.

Üngör, İbrahim. “Türk Kültüründe Dağ Keçisi Teke.” IV. Uluslararası Türk Şöleni Türk Kültürü Sempozyuти Bildirileri (17-19 Mayıs 2016 Erzurum), Erzurum: Güneş Vakfı Yayınları, 2018, 245-325.

Üngör, İbrahim. “Orta Asya'dan Anadolu’ya Kayalara Yazılan Türk Kültürü (Dereiçi Kaya Resimleri)”, Selçuk Üniversitesi Türkiyat Araştırmaları Dergisi 39, 2016: 357-370. 
Vary, Hermann. "Alttürkische in Nordeast-Anatolien Ural-Altaische.” Jahrbücher 40/1-2 (1968): 50-78.

Y1lmaz, An1l ve Cahit Telci. “Türk Kültür Terminolojisinde Göç Kavramı Üzerine.” Modern Türklük Araştırmaları Dergisi 7/2 (2010): 14-33.

Y1lmaz, Anıl. "İskit Sanatı.” Türkler Ansiklopedisi. c. 4. Ankara: Yeni Türkiye Yayınları, 2002, 26-32. 
